\title{
What prevents nitrogen depletion in the oxygen minimum zone of the eastern tropical South Pacific?
}

\author{
B. Su, M. Pahlow, H. Wagner, and A. Oschlies \\ GEOMAR Helmholtz Centre for Ocean Research Kiel, Marine Biogeochemical Modelling, \\ Düsternbrooker Weg 20, 24105 Kiel, Germany \\ Correspondence to: B. Su (bsu@geomar.de)
}

Received: 11 June 2014 - Published in Biogeosciences Discuss.: 18 July 2014

Revised: 19 December 2014 - Accepted: 27 January 2015 - Published: 24 February 2015

\begin{abstract}
Local coupling between nitrogen fixation and denitrification in current biogeochemical models could result in runaway feedback in open-ocean oxygen minimum zones (OMZs), eventually stripping OMZ waters of all fixed nitrogen. This feedback does not seem to operate at full strength in the ocean, as nitrate does not generally become depleted in open-ocean OMZs. To explore in detail the possible mechanisms that prevent nitrogen depletion in the OMZ of the eastern tropical South Pacific (ETSP), we develop a box model with fully prognostic cycles of carbon, nutrients and oxygen in the upwelling region and its adjacent open ocean. Ocean circulation is calibrated with $\Delta^{14} \mathrm{C}$ data of the ETSP. The sensitivity of the simulated nitrogen cycle to nutrient and oxygen exchange and ventilation from outside the model domain and to remineralization scales inside an OMZ is analysed. For the entire range of model configurations explored, we find that the fixed-N inventory can be stabilized at nonzero levels in the ETSP OMZ only if the remineralization rate via denitrification is slower than that via aerobic respiration. In our optimum model configuration, lateral oxygen supply into the model domain is required at rates sufficient to oxidize at least about one fifth of the export production in the model domain to prevent anoxia in the deep ocean. Under these conditions, our model is in line with the view of phosphate as the ultimate limiting nutrient for phytoplankton, and implies that for the current notion of nitrogen fixation being favoured in N-deficit waters, the water column of the ETSP could even be a small net source of nitrate.
\end{abstract}

\section{Introduction}

The oceanic fixed nitrogen (fixed-N) budget is an essential control on the potential of the ocean to sequester atmospheric $\mathrm{CO}_{2}$ via the marine biological pump. Denitrification is generally recognized as a major loss of fixed nitrogen, whereas the balance of the global oceanic nitrogen budget remains controversial. Accordingly, estimates derived from both field data and model analyses for the global oceanic fixed-N budget range from sources roughly balancing sinks (Gruber and Sarmiento, 1997; Gruber, 2004; Eugster and Gruber, 2012; DeVries et al., 2013) to a rather large net deficit between 140 and $234 \mathrm{Tg} \mathrm{Nyr}^{-1}$ (Codispoti et al., 2001; Galloway et al., 2004; Codispoti, 2007).

One of the main uncertainties in the global marine nitrogen budget is the extent of nitrogen loss via denitrification and anaerobic ammonium oxidation (anammox) in oxygen minimum zones (OMZs), located in tropical coastal upwelling regions. Coastal upwelling zones are often associated with very high primary production. Subsequent decomposition of sinking organic matter leads to high levels of oxygen consumption in subsurface waters. Under conditions of sluggish circulation, oxygen-poor source waters, or lack of exchange with oxygenated surface waters, OMZs can develop, usually at intermediate depths of about 200-700 m (Bethoux, 1989; Capone and Knapp, 2007). An OMZ is commonly defined as a water body with an $\mathrm{O}_{2}$ concentration below $20 \mu \mathrm{molL} \mathrm{L}^{-1}$ (Paulmier and Ruiz-Pino, 2009). The four major open-ocean OMZs are in the eastern North Pacific (ENP), the eastern tropical South Pacific (ETSP), the Arabian Sea, and the Bay of Bengal. OMZs currently account for only about $8 \%$ of the global ocean area but observations of intense denitrification and anammox in the OMZs indicate that they could 
be responsible for $30-50 \%$ of the total fixed-N loss (Gruber and Sarmiento, 1997; Codispoti et al., 2001; Dalsgaard et al., 2005; Paulmier and Ruiz-Pino, 2009).

Canfield (2006) used a simple steady-state box model of a coastal OMZ to show that a positive feedback between $\mathrm{N}_{2}$ fixation and denitrification could strip the OMZ of all fixed nitrogen when $\mathrm{N}_{2}$ fixation was permitted to restore the nitrate: phosphate ratio to Redfield proportions in the surface ocean. Observed concentrations of fixed-N (nitrate plus nitrite) in OMZ waters, however, typically range from about 15 to $40 \mu \mathrm{mol} \mathrm{L}^{-1}$ (Codispoti and Richards, 1976; Codispoti and Packard, 1980; Morrison et al., 1998; Voss et al., 2001). A possible explanation for the relatively high nitrate concentrations even in the suboxic core of open-ocean OMZs could be low levels of nitrogen fixation in the overlying surface waters (Landolfi et al., 2013). However, recent interpretations of observed fixed- $\mathrm{N}$ deficits relative to the Redfield equivalent of phosphorus point to high rates of nitrogen fixation closely related to the upwelling of nitrogen-deficit waters along the South American coast (Deutsch et al., 2007). Although alternative explanations for these nutrient patterns have been proposed in models (Mills and Arrigo, 2010), direct measurements have confirmed the occurrence of nitrogen fixation in and above the OMZ of the ETSP (Fernandez et al., 2011). Global biogeochemical models also generally predict substantial rates of $\mathrm{N}_{2}$ fixation in the nitrate-deficit waters of the upwelling region of the ETSP that, if not compensated for by some ad hoc slow-down of remineralization in suboxic conditions, lead to a complete draw-down of nitrate in the OMZ (Moore and Doney, 2007; Schmittner et al., 2008). The question of how non-zero nitrate concentrations can be maintained in the OMZ thus still awaits a mechanistic answer.

The computational efficiency of box models makes them suitable for sensitivity analyses requiring thousands of model evaluations. In spite of its simplicity, Canfield's (2006) box model is also able to capture the most important first-order interactions among ocean circulation, nitrogen fixation, denitrification and OMZs. However, Canfield's model was limited in its power to investigate the influence of open ocean nutrients and oxygen conditions on the upwelling region, because its dynamics were restricted to the OMZ, where all biogeochemical tracers were prescribed in the surrounding waters. Based on Canfield's (2006) steady-state formulation with prescribed oxygen and nutrient concentrations at all depths outside the OMZ, we here present a fully prognostic box model of $\mathrm{NO}_{3}^{-}, \mathrm{PO}_{4}^{3-}$ and $\mathrm{O}_{2}$ cycles in a coastal upwelling region and an adjacent ocean basin. We employ this model to examine under which conditions the observed situation of an essentially complete drawdown of subsurface oxygen and an incomplete drawdown of nitrate can be reproduced for the case of the ETSP. Sensitivity experiments explore how nutrient exchange and oxygen ventilation from the southern boundary influence the nitrogen budget within the model domain.
By including a prognostic description not only of conditions within the OMZ, but also in the water surrounding it, we aim to represent local as well as spatially separated feedbacks between the relatively small OMZ and the much larger open-ocean basin. The model describes net primary and export production by ordinary and $\mathrm{N}_{2}$-fixing phytoplankton, as well as aerobic and anaerobic remineralization. The latter is generally associated with nitrogen loss, commonly attributed to denitrification (Codispoti, 1995). Anammox has recently been reported as another major pathway for fixed-N removal (Kuypers et al., 2005; Hamersley et al., 2007; Molina and Farías, 2009), but the relative contributions of anammox and denitrification are still a matter of debate (Ward et al., 2009; Bulow et al., 2010). In our model, we do not explicitly resolve the different inorganic nitrogen species and pragmatically consider all loss of fixed-N via anaerobic remineralization as denitrification. In Canfield's (2006) model, most of the physical model parameters were constrained by observations from suboxic upwelling zones in the Arabian Sea and the eastern tropical North and South Pacific. The physical dynamics of our model system are governed by vertical and horizontal mixing and advection, which are calibrated with $\Delta{ }^{14} \mathrm{C}$ data of the ETSP from GLODAP (Global Ocean Data Analysis Project, Key et al., 2004).

\section{Model description}

Figure 1 shows the model structure, consisting of five boxes representing an upwelling region and an adjacent ocean basin. The U box represents the upper upwelling region. The UM box is the underlying OMZ, where suboxia is expected to develop. The $\mathrm{S}$ box represents the surface ocean away from the upwelling zone. Below the S box sits the I box, which represents water of intermediate depth and exchanges water with UM. D is the deep box, which represents water deeper than $500 \mathrm{~m}$. When the UM, I or D boxes become suboxic, denitrification (Denif) will ensue to remineralize the exported organic matter, causing a loss of nitrate (the only form of fixed inorganic nitrogen in our model).

Prognostic tracers represent $\mathrm{NO}_{3}^{-}, \mathrm{PO}_{4}^{3-}, \mathrm{O}_{2},{ }^{14} \mathrm{C}$ and the biomass of ordinary and $\mathrm{N}_{2}$-fixing phytoplankton, respectively (Table 1). The rate of concentration change of a tracer, $X_{i}$, in box $i$ is composed of physical transport, $\operatorname{Transport}\left(X_{i}\right)$, and a sources-minus-sinks term, $\operatorname{SMS}\left(X_{i}\right)$, which represents the effects of biotic processes, air-sea gas exchange and, in the case of ${ }^{14} \mathrm{C}$, radioactive decay on the tracer concentration (Eq. 1).

$$
\frac{\mathrm{d} X_{i}}{\mathrm{~d} t}=\frac{\operatorname{Transport}\left(X_{i}\right)+\operatorname{SMS}\left(X_{i}\right)}{V_{i}}
$$

where U, S, UM, I and D refer to the model boxes defined above and $V_{i}$ to the corresponding volumes (Fig. 1). 


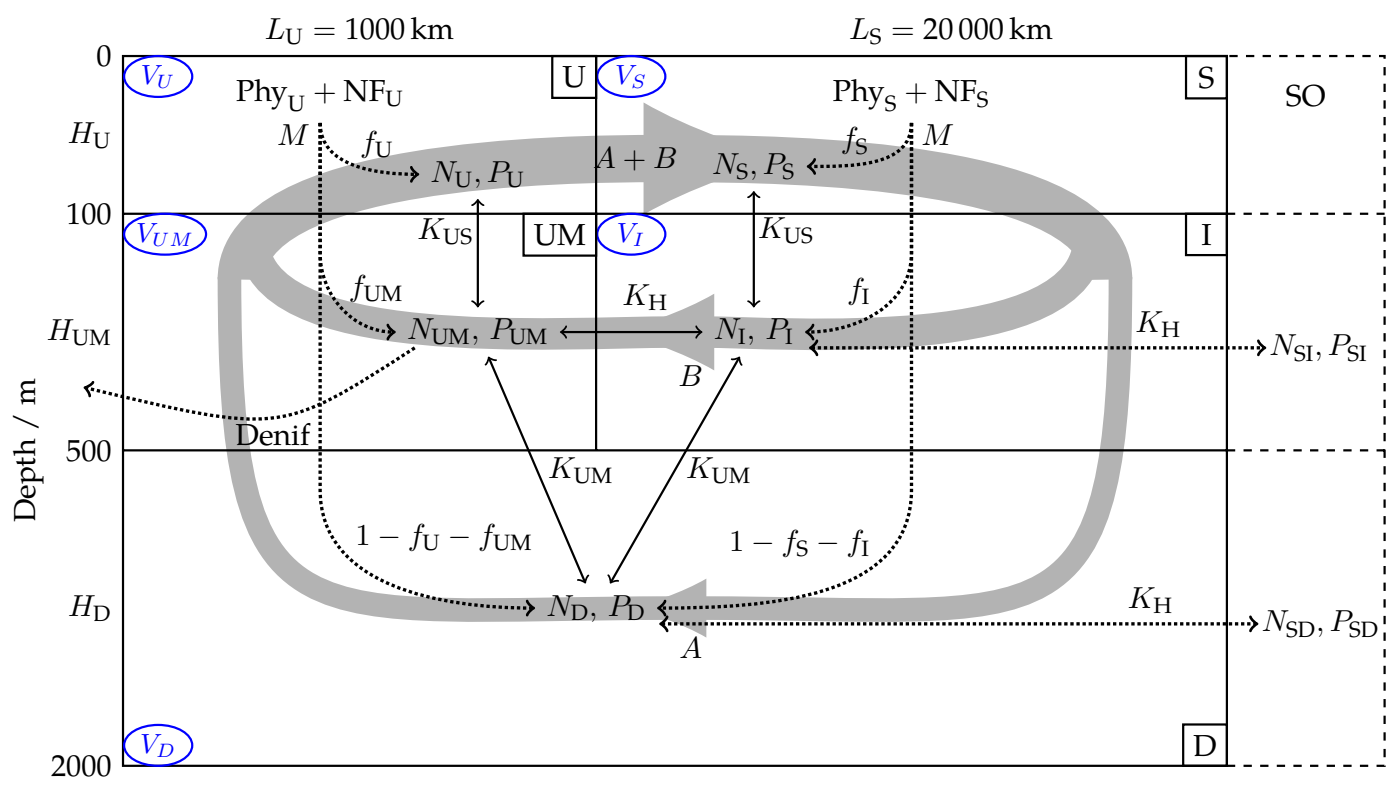

Figure 1. Model structure and configurations. The model domain comprises five active boxes representing the top $100 \mathrm{~m}$ of an upwelling region (U), the underlying oxygen minimum zone (UM), and an adjacent open-ocean basin divided into a surface (S) and an intermediatedepth box (I). A deep box (D) underlies both the upwelling region and the open ocean. The large-scale circulation is represented by deep ( $A$ ) and shallow $(B)$ convection (thick grey lines). Mixing between boxes is implemented via mixing coefficients $(K)$. Remineralization derived from net primary production by ordinary (Phy) and diazotrophic (NF) phytoplankton in the surface boxes consumes oxygen. Under anoxic conditions remineralization is fuelled by anaerobic remineralization (Denif). The model can be configured to exchange nutrients and oxygen with the southern subtropical ocean (right, denoted as "SO"). See Table 3 for symbol definitions and text for details.

Table 1. Model variables.

\begin{tabular}{|c|c|c|c|}
\hline Variables & Units & Description & Equation \\
\hline $\mathrm{Phy}_{i}$ & $\mu \mathrm{mol} \mathrm{N} \mathrm{kg}{ }^{-1}$ & Ordinary phytoplankton in box $i$ & Eq. (2) \\
\hline $\mathrm{NF}_{i}$ & $\mu \mathrm{mol} \mathrm{N} \mathrm{kg}{ }^{-1}$ & Nitrogen fixers in box $i$ & Eq. (3) \\
\hline $\mathrm{N}_{i}$ & $\mu \mathrm{mol} \mathrm{N} \mathrm{kg}{ }^{-1}$ & Nitrate concentration in box $i$ & Eq. (7) \\
\hline $\mathrm{N}_{\mathrm{avg}}$ & $\mu \mathrm{mol} \mathrm{N} \mathrm{kg}{ }^{-1}$ & Average nitrogen concentration & \\
\hline $\mathrm{P}_{i}$ & $\mu \mathrm{mol} \mathrm{P} \mathrm{kg}-1$ & Phosphate concentration in box $i$ & Eq. (8) \\
\hline $\mathrm{P}_{\mathrm{avg}}$ & $\mu \mathrm{mol} \mathrm{P} \mathrm{kg}-1$ & Average phosphorus concentration & \\
\hline $\mathrm{O}_{2 i}$ & $\mu \mathrm{mol} \mathrm{kg}-1$ & Oxygen concentration in box $i$ & Eq. (9) \\
\hline
\end{tabular}

\subsection{Transport model}

Advection represents the large-scale circulation and is indicated in Fig. 1 by wide grey lines. $L_{\mathrm{U}}$ and $L_{\mathrm{S}}$ are the horizontal scales of the upwelling region and the open ocean, and $H_{\mathrm{U}}, H_{\mathrm{UM}}$ and $H_{\mathrm{D}}$ refer to the thickness of the respective boxes. The volumes $V_{i}$ of the boxes are defined in this 2-D model by $V_{i}=H_{i} \times L_{i} . K_{\mathrm{US}}, K_{\mathrm{UM}}$ and $K_{\mathrm{H}}$ are the coefficients of mixing between different boxes. $A$ and $B$ represent the deep and shallow large-scale circulation. The upwelling intensity into box $\mathrm{U}$ is given by $A+B$. The tracer transport equations for the standard configuration are given in Appendix A (Eqs. A1-A5). All parameters are defined in Tables 2 and 3.

\subsection{Biogeochemical model}

The ecological model is composed of two phytoplankton types, ordinary phytoplankton, Phy, and nitrogen fixers, NF. 
Table 2. Parameters of the physical model configurations. Detailed explanations for these parameters are given in Table 3.

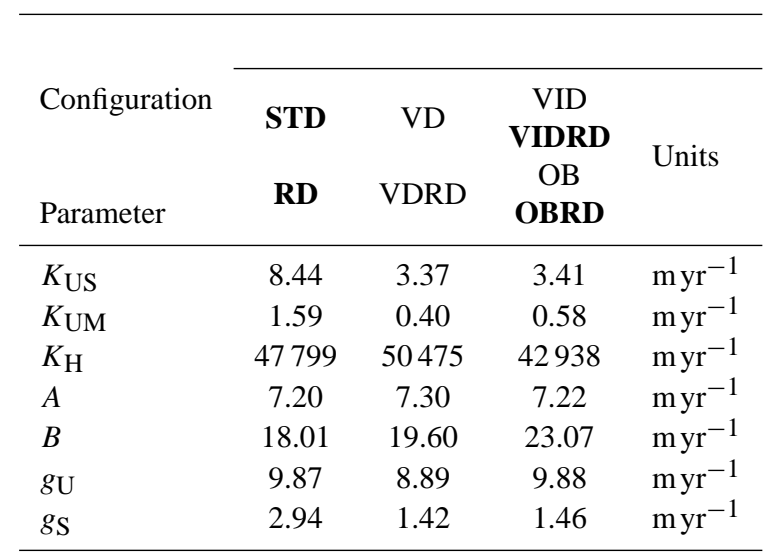

Configurations in bold are the main configurations.

The SMS terms for phytoplankton are obtained as the difference between net primary production (NPP) and mortality (M):

$\operatorname{SMS}\left(\mathrm{Phy}_{i}\right)=\left(\mathrm{NPP}^{\mathrm{Phy}_{i}}-\mathrm{M}^{\mathrm{Phy}_{i}}\right) \cdot V_{i} \quad i \in[\mathrm{U}, \mathrm{S}]$

$\operatorname{SMS}\left(\mathrm{NF}_{i}\right)=\left(\mathrm{NPP}^{\mathrm{NF}_{i}}-\mathrm{M}^{\mathrm{NF}_{i}}\right) \cdot V_{i} \quad i \in[\mathrm{U}, \mathrm{S}]$.

Growth of ordinary phytoplankton is described by a Liebig-type dependence on the nitrate and phosphate limitation terms (Eq. 4),

$\mathrm{NPP}^{\mathrm{Phy}_{i}}=\mu \cdot \min \left(\frac{\mathrm{N}_{i}}{\mathrm{~N}_{i}+\mathrm{N}_{\mathrm{h}}}, \frac{\mathrm{P}_{i}}{\mathrm{P}_{i}+\mathrm{P}_{\mathrm{h}}}\right) \cdot \mathrm{Phy}_{i}$

$i \in[\mathrm{U}, \mathrm{S}]$

$\mathrm{NPP}^{\mathrm{NF}_{i}}=\mu_{\mathrm{NF}} \cdot \frac{\mathrm{P}_{i}}{\mathrm{P}_{i}+\mathrm{P}_{\mathrm{h}}} \cdot \mathrm{NF}_{i} \quad i \in[\mathrm{U}, \mathrm{S}]$

where $i$ is the model box, $\mu$ and $\mu_{\mathrm{NF}}$ are the maximum growth rates of $\mathrm{Phy}_{i}$ and $\mathrm{NF}_{i}$, respectively. $\mathrm{N}_{i}$ and $\mathrm{P}_{i}$ are nitrate and phosphate concentrations, and $\mathrm{N}_{h}$ and $\mathrm{P}_{\mathrm{h}}$ are halfsaturation concentrations for nitrate and phosphate. Considering possible viral lysis, phytoplankton aggregation, or a feedback between zooplankton grazing and phytoplankton concentration, a quadratic mortality term is adopted for both Phy and NF in all model configurations (Eq. 6).

$\mathrm{M}^{\mathrm{Phy}_{i}}=M_{\mathrm{q}} \cdot \mathrm{Phy}_{i}^{2} \quad \mathrm{M}^{\mathrm{NF}_{i}}=M_{\mathrm{q}} \cdot \mathrm{NF}_{i}^{2}$.

Both Phy and NF require phosphate, whereas nitrate is required in addition to phosphate only by Phy, and NF can fix $\mathrm{N}_{2}$ as long as $\mathrm{PO}_{4}^{3-}$ is available (Eqs. 4, 5). While the ability to utilize organic $\mathrm{P}$ has been proposed as an advantage of diazotrophs (Houlton et al., 2008; Ye et al., 2012), ordinary phytoplankton can also use DOP (e.g. Chu, 1946; Cotner, Jr. and Wetzel, 1992) and a clear advantage of diazotrophs over ordinary phytoplankton in the presence of DOP has never been demonstrated. Thus, we treat all available $\mathrm{P}$ to phytoplankton operationally as $\mathrm{PO}_{4}^{3-}$ and assume that all organic phosphate is remineralized to $\mathrm{PO}_{4}^{3-}$ directly. $\mathrm{N}_{2}$ fixers are given a lower maximum growth rate ( $\mu_{\mathrm{NF}}$, Eq. 5$)$, which is $1 / 3$ of the maximum growth rate of ordinary phytoplankton $(\mu)$, to account for the high cost of nitrogen fixation (La Roche and Breitbarth, 2005). The dependence of NF on iron is not explicitly considered in this model (Mills et al., 2004). Both types use nitrogen and phosphorus in the Redfield ratio of $16: 1$ (Redfield et al., 1963).

Sensitivity experiments are also performed with a configuration where nitrogen fixers preferentially use nitrate when available and cover only the residual nitrogen demand via $\mathrm{N}_{2}$ fixation, denoted as facultative $\mathrm{N}_{2}$-fixation, but overall results are found to be virtually unchanged (Appendix B).

Dead phytoplankton is immediately remineralized in the surface layer and underlying boxes according to the respective remineralization fraction $f_{i}$ of box $i$. Remineralization occurs preferentially via aerobic respiration, with anaerobic remineralization and the associated nitrogen loss setting in only when all $\mathrm{O}_{2}$ has been consumed by aerobic respiration. Phytoplankton growth and aerobic remineralization together with denitrification and, once all inorganic nitrogen is consumed, remineralization via sulfate reduction define the SMS terms of the nitrogen and phosphorus cycles:

$$
\begin{aligned}
& \operatorname{SMS}\left(N_{i}\right)=-\mathrm{NPP}^{\mathrm{Phy}_{i}} \cdot V_{i}+\mathrm{Rem}_{i}^{\mathrm{N}}-\text { Denif }_{i} \\
& \operatorname{SMS}\left(\mathrm{P}_{i}\right)=-\frac{\left(\mathrm{NPP}^{\mathrm{Phy}_{i}}+\mathrm{NPP}^{\mathrm{NF}_{i}}\right) \cdot V_{i}}{r_{\mathrm{p}}}+\operatorname{Rem}_{i}^{\mathrm{P}}
\end{aligned}
$$

where the remineralization (Rem) and denitrification (Denif) terms are defined in Appendix C.

$\mathrm{O}_{2}$ is set constant in the surface ocean boxes $\mathrm{U}$ and $\mathrm{S}$, which are in immediate contact with the atmosphere, but varies as a function of transport and respiration in the UM, I and $\mathrm{D}$ boxes. Thus, the aerobic respiration terms $\left(\operatorname{Res}_{i}\right)$ are only needed in the interior boxes UM, I and D:

$\operatorname{SMS}\left(\mathrm{O}_{2 i}\right)=-\operatorname{Res}_{i} \quad i \in[\mathrm{UM}, \mathrm{I}, \mathrm{D}]$

where Res is defined in Appendix C (Eq. C10). Note that aerobic respiration will, in general, also take place in anoxic model boxes, where it utilizes the $\mathrm{O}_{2}$ transported from adjacent boxes, before anaerobic respiration starts. All model runs are initialized with $\mathrm{O}_{2}, \mathrm{NO}_{3}^{-}$and $\mathrm{PO}_{4}^{3-}$ annual data from the World Ocean Atlas 2009 (Garcia et al., 2010a, b), averaged over the regions indicated in Table 4.

\subsection{Model calibration}

In the present work, the prescribed transport among the different boxes in terms of advection and mixing was calibrated by fitting the modelled $\Delta^{14} \mathrm{C}$ distribution to the GLODAP "pre-bomb" $\Delta{ }^{14} \mathrm{C}$ distribution of the eastern tropical South Pacific (Key et al., 2004; Table 4). The ${ }^{13} \mathrm{C}$ fractionationcorrected ratio of ${ }^{14} \mathrm{C} /{ }^{12} \mathrm{C}, \Delta{ }^{14} \mathrm{C}$, is commonly used in ocean modelling to evaluate and calibrate model physics 
Table 3. Model parameters.

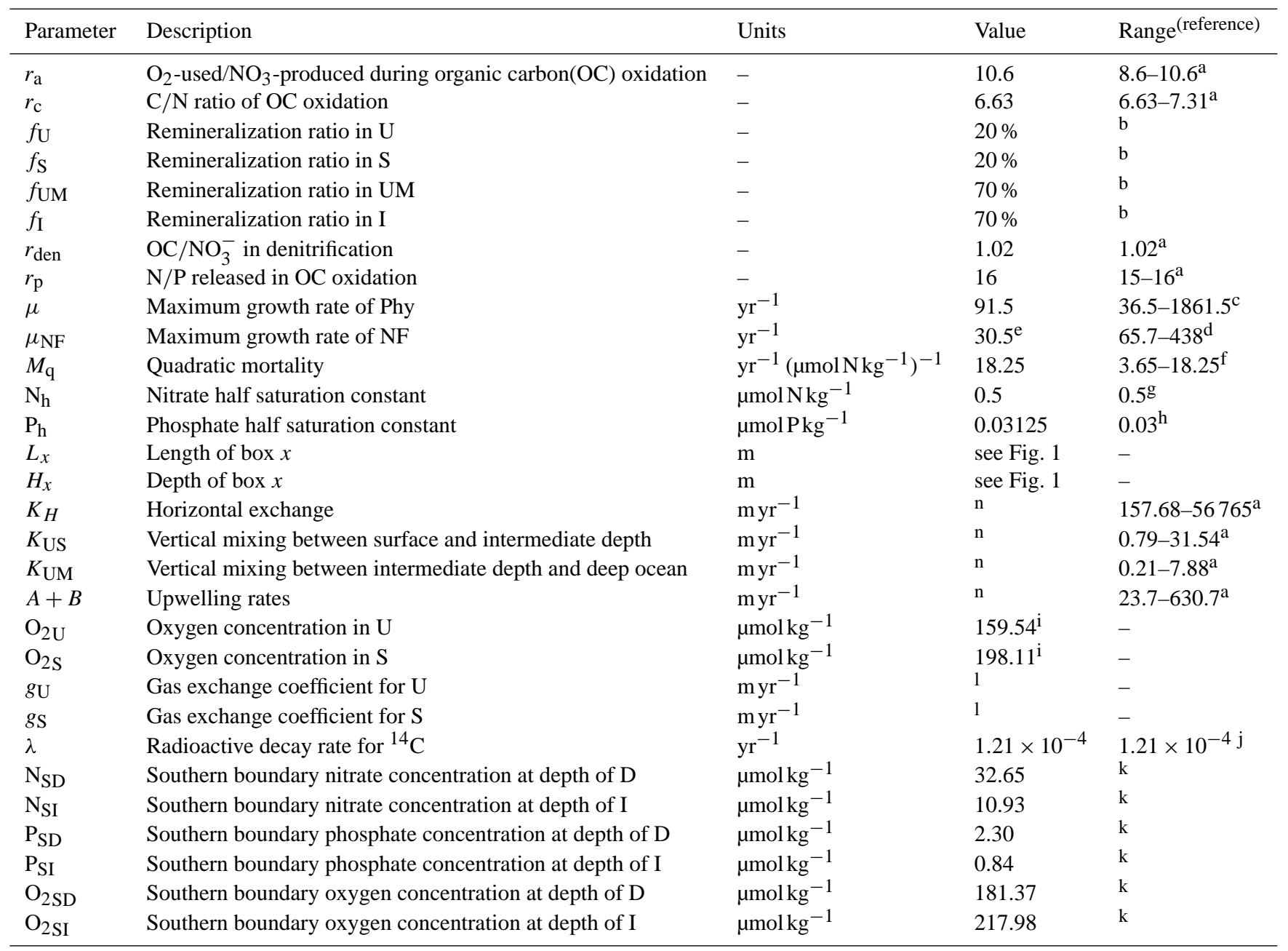

a Ranges for $r_{\mathrm{a}}, r_{\mathrm{c}}, r_{\mathrm{den}}, K_{\mathrm{US}}, K_{\mathrm{UM}}, K_{\mathrm{H}}, A$ and $B$ are the same as in Canfield (2006).

$\mathrm{b}$ The fraction of regeneration above $500 \mathrm{~m}$ has been estimated between $92 \%$ (Suess, 1980) and $97 \%$ (Martin et al., 1987). According to Canfield (2006), most likely 60-70\% of the primary production is remineralized in the OMZ. Thus, we define 20 and $70 \%$ of export production remineralized in the surface boxes and intermediate boxes, respectively.

c Furnas (1990)

d Robarts and Zohary (1987); Capone et al. (1997)

e Temperature-corrected maximum growth rate of NF (Breitbarth et al., 2007).

${ }^{\mathrm{f}}$ Palmer and Totterdell (2001); Schmittner et al. (2008)

g Eppley et al. (1969)

${ }^{\mathrm{h}}$ McAllister et al. (1964)

${ }^{\mathrm{i}}$ Average $0-100 \mathrm{~m} \mathrm{O}_{2}$ concentrations of the corresponding areas from World Ocean Atlas (2009).

j Libby (1956)

${ }^{\mathrm{k}}$ Averages of the corresponding areas from World Ocean Atlas (2009).

${ }^{1}$ These parameter values are defined in Table 2 .

(Toggweiler et al., 1989; Shaffer and Sarmiento, 1995) because it tends to cancel the effect of the biotic downward transport of ${ }^{14} \mathrm{C}$ with the rain of organic particles produced by marine organisms. For practical reasons, we employ the arbitrary scale introduced by Shaffer and Sarmiento (1995) to represent $\Delta^{14} \mathrm{C}$, and define $\widehat{\Delta^{14} \mathrm{C}} \cdot \widehat{\Delta^{14} \mathrm{C}}$ can be converted to $\Delta^{14} \mathrm{C}$ units as follows:

$\Delta^{14} \mathrm{C}=1000\left(\widehat{\Delta^{14} \mathrm{C}}-1\right) \%$
The ${ }^{14} \mathrm{C}$ dynamics in the model includes input from the atmosphere at the sea surface and radioactive decay with decay rate $\lambda=1.21 \times 10^{-4} \mathrm{yr}^{-1}$ within the model domain. 
Table 4. $\Delta^{14} \mathrm{C}$ (in \%o) data from GLODAP used for calibration of the model physical parameters.

\begin{tabular}{crlrc}
\hline Box & Lat $(\mathrm{S})$ & Long $(\mathrm{W})$ & Depth $(\mathrm{m})$ & Data $^{\mathrm{a}}$ \\
\hline $\mathrm{U}$ & $5-15$ & $80-90$ & $0-100$ & -72.39 \\
$\mathrm{UM}$ & $5-15$ & $80-90$ & $100-500$ & -93.28 \\
$\mathrm{~S}$ & $0-20$ & $90-190$ & $0-100$ & -62.21 \\
$\mathrm{I}$ & $0-20$ & $90-190$ & $100-500$ & -81.02 \\
$\mathrm{D}$ & $0-20$ & $80-190$ & $500-2000$ & -160.30 \\
$\mathrm{SI}^{\mathrm{b}}$ & $20-40$ & $90-190$ & $100-500$ & -71.02 \\
$\mathrm{SD}^{\mathrm{b}}$ & $20-40$ & $80-190$ & $500-2000$ & -134.4 \\
\hline
\end{tabular}

${ }^{a}$ GLODAP natural ${ }^{14} \mathrm{C}$ data averaged over the respective regions. ${ }^{\mathrm{b}} \mathrm{SI}$ and SD represent the southern boundary outside the I and D boxes, respectively.

The SMS term for $\widehat{\Delta^{14} \mathrm{C}}$ is thus given by:

$$
\begin{aligned}
\operatorname{SMS}\left(\widehat{\Delta^{14} C_{i}}\right) & =\left(\frac{g_{i}\left(\widehat{\Delta^{14} C_{a}}-\widehat{\Delta^{14} C_{i}}\right)}{H_{i}}-\lambda \widehat{\Delta^{14} C_{i}}\right) \cdot V_{i} \\
i & \in[\mathrm{U}, \mathrm{UM}, \mathrm{S}, \mathrm{I}, \mathrm{D}]
\end{aligned}
$$

where $\widehat{\Delta^{14} C_{i}}$ is the value of $\widehat{\Delta^{14} \mathrm{C}}$ in box $i, \widehat{\Delta^{14} \mathrm{C}_{\mathrm{a}}}$ is the atmospheric $\widehat{\Delta^{14} \mathrm{C}}$, and $g_{i}$ is the gas exchange rate. For $i \in$ [UM, I, D], $g_{i}=0$. We assume that the $\Delta^{14} \mathrm{C}$ of the preindustrial atmosphere, $\Delta{ }^{14} \mathrm{C}_{\mathrm{a}}$, is $0 \%$. Therefore, $\widehat{\Delta^{14} \mathrm{C}_{\mathrm{a}}}$ is 1 . Model configurations with an open southern boundary also include ${ }^{14} \mathrm{C}$ exchange with the adjacent subtropical ocean. We also investigate how sensitive our main conclusions are to the uncertainty in the $\Delta{ }^{14} \mathrm{C}$ data. Table 4 shows the $\Delta^{14} \mathrm{C}$ values used for the calibrations of the different model configurations. Transport and SMS terms for $\widehat{{ }^{14} \mathrm{C}}$ constitute a system of 5 linear equations with 7 parameters, including 5 transport parameters, $A, B, K_{\mathrm{US}}, K_{\mathrm{UM}}, K_{\mathrm{H}}$, and 2 air-sea $\widehat{{ }^{14} \mathrm{C}}$ exchange coefficients, $g_{\mathrm{U}}$ and $g_{\mathrm{S}}$. After setting $g_{\mathrm{U}}$ and $g_{S}$, the 5 equations can be inverted to solve for the transport parameters. A detailed description of the inversion scheme is provided in Appendix D.

\subsection{Model configurations}

The above transport and biogeochemical formulations define the standard (STD) configuration, where the transport and biogeochemical models are applied without exchange with the southern boundary ("SO" in Fig. 1). Fixed fractions $f_{i}$ of net primary production in $\mathrm{U}$ and $\mathrm{S}$ are remineralized in the U, UM, S and I boxes, with the remainder being remineralized in D (Fig. 1). Nutrient regeneration is assumed to be instantaneous.

In order to investigate the relationships between the different biotic and physical processes and the nitrogen cycle in an OMZ, we introduce seven additional model configurations. The main differences to the STD configuration are shown in Table 5.
(1) In the Reduced-denitrification (RD) configuration, denitrification in the OMZ is reduced to $1 / 5$ of the rate of the STD configuration following the procedure applied in the global biogeochemical circulation model by Schmittner et al. (2008). When oxygen is exhausted in the OMZ, denitrification within the UM box will be responsible for only $1 / 5$ of the remaining organic matter remineralization and the remainder will be remineralized in the D box (Eqs. C7 and C8). (2) The Ventilation-D (VD) configuration modifies the STD configuration in that the southern boundary of the model domain is partially opened to allow ventilation of $\mathrm{O}_{2}$ and ${ }^{14} \mathrm{C}$ (but not $\mathrm{NO}_{3}^{-}$and $\mathrm{PO}_{4}^{3-}$ ) to the $\mathrm{D}$ box from the southern subtropical ocean (Eq. A7). The circulation parameters were recalibrated to account for ventilation of ${ }^{14} \mathrm{C}$ from the south. Ventilation is simulated by applying lateral mixing with the subtropical oligotrophic ocean tracer reservoirs with prescribed ${ }^{14} \mathrm{C}$ and $\mathrm{O}_{2}$ concentrations inferred from observations. All other biogeochemical processes within the model domain are kept the same as in the STD configuration. (3) In the Ventilation-D + Reduced-denitrification (VDRD) configuration, the reduced denitrification rate is applied in the VD configuration. (4) In the Ventilation-ID (VID) configuration, the partially open southern boundary is extended to allow ventilation of $\mathrm{O}_{2}$ and ${ }^{14} \mathrm{C}$ also into the I box from the subtropical ocean (Eq. A6). Again, circulation parameters are recalibrated against observed $\Delta{ }^{14} \mathrm{C}$ taking into account the ${ }^{14} \mathrm{C}$ exchange between the subtropical ocean and the I and $\mathrm{D}$ boxes. (5) In the Ventilation-ID + Reduced-denitrification (VIDRD) configuration, the reduced denitrification rate is also applied in the VID configuration. (6) In the Open-boundary (OB) configuration, nutrient mixing is added to the VID configuration to allow for the exchange of nutrients between the I and D boxes and the subtropical ocean. (7) In the Openboundary + Reduced-denitrification (OBRD) configuration, the reduced-denitrification rate is again added to the $\mathrm{OB}$ configuration. The physical transports of $\mathrm{NO}_{3}^{-}$and $\mathrm{PO}_{4}^{3-}$ for the $\mathrm{I}$ and $\mathrm{D}$ boxes in the last six configurations are represented by Eqs. (A6) and (A7) in Appendix A.

\subsection{Sensitivity experiments}

Two sensitivity experiments are performed for each of the VID and OB configurations to explore the possibilities for preventing $\mathrm{NO}_{3}^{-}$depletion in the OMZ: (a) different reduced remineralization rates $\left(f_{\mathrm{UM}}\right)$ and (b) facultative $\mathrm{N}_{2}$-fixation (see Appendix E).

For the OBRD configuration, three sensitivity experiments are performed to investigate our model sensitivity to variable physical transports and biogeochemical tracer concentrations: (1) the mixing rate with the southern boundary, $K_{\mathrm{H}}$, is reduced for individual tracers (nutrients, oxygen) or combinations thereof from full rates to zero. (2) Simulations are repeated with individual circulation parameters varied by $\pm 50 \%$ to explore the sensitivity with respect to the circulation parameters of the box model. (3) The sensitivity of $\mathrm{NO}_{3}^{-}$ 


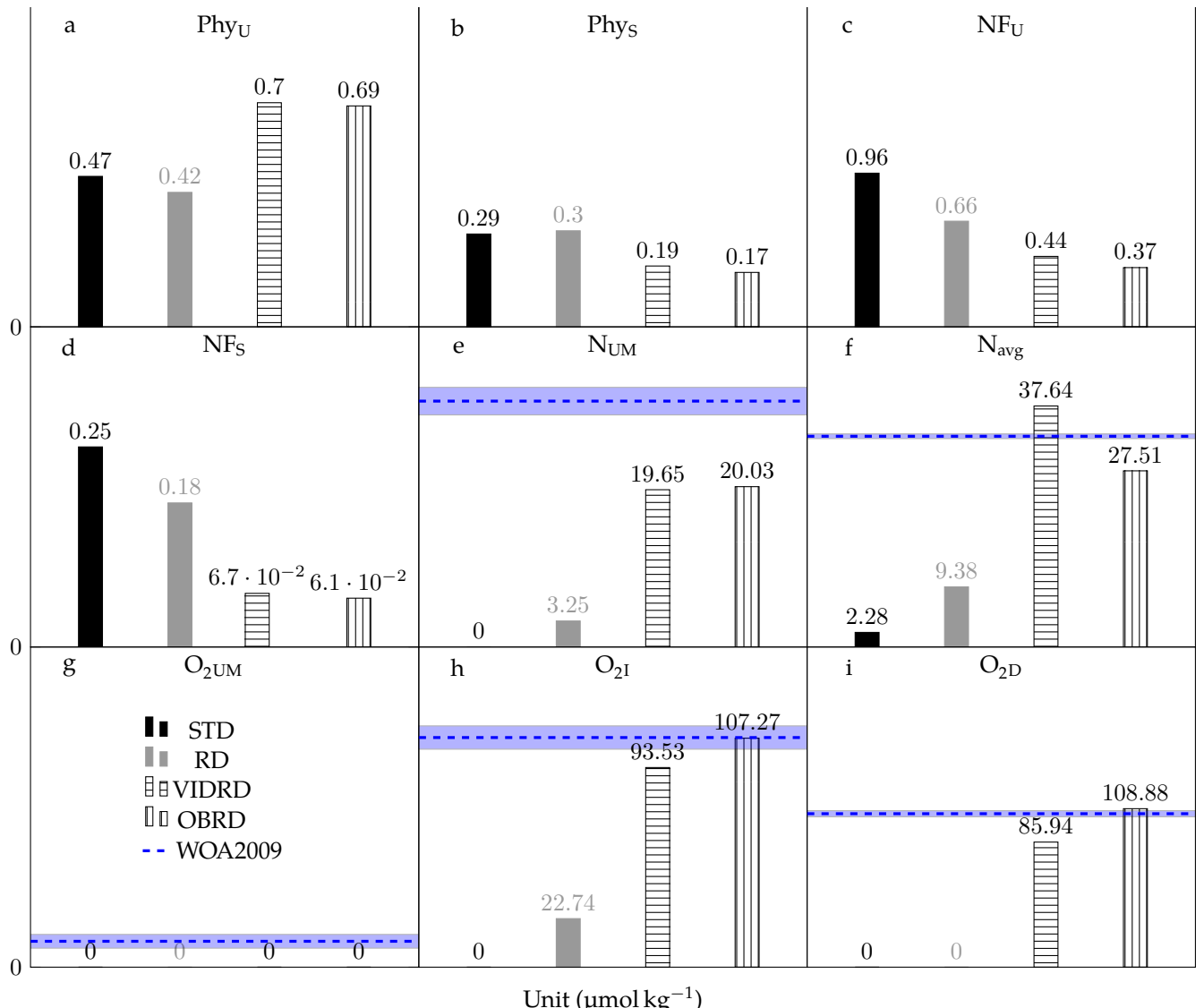

Figure 2. Simulated steady-state phytoplankton, nutrient and oxygen concentrations for the main model configurations defined in Tables 5 and 2. Each panel uses a linear scale of the $y$ axis starting at zero. Dashed blue lines represent the averages of the WOA2009 nitrate and oxygen data for the corresponding boxes, and the light blue shadings refer to the $95 \%$ confidence intervals; however, there are no data for $\mathrm{Phy}_{U}, \mathrm{Phy}_{\mathrm{S}}, \mathrm{NF}_{\mathrm{U}}$ and $\mathrm{NF}_{S}$.

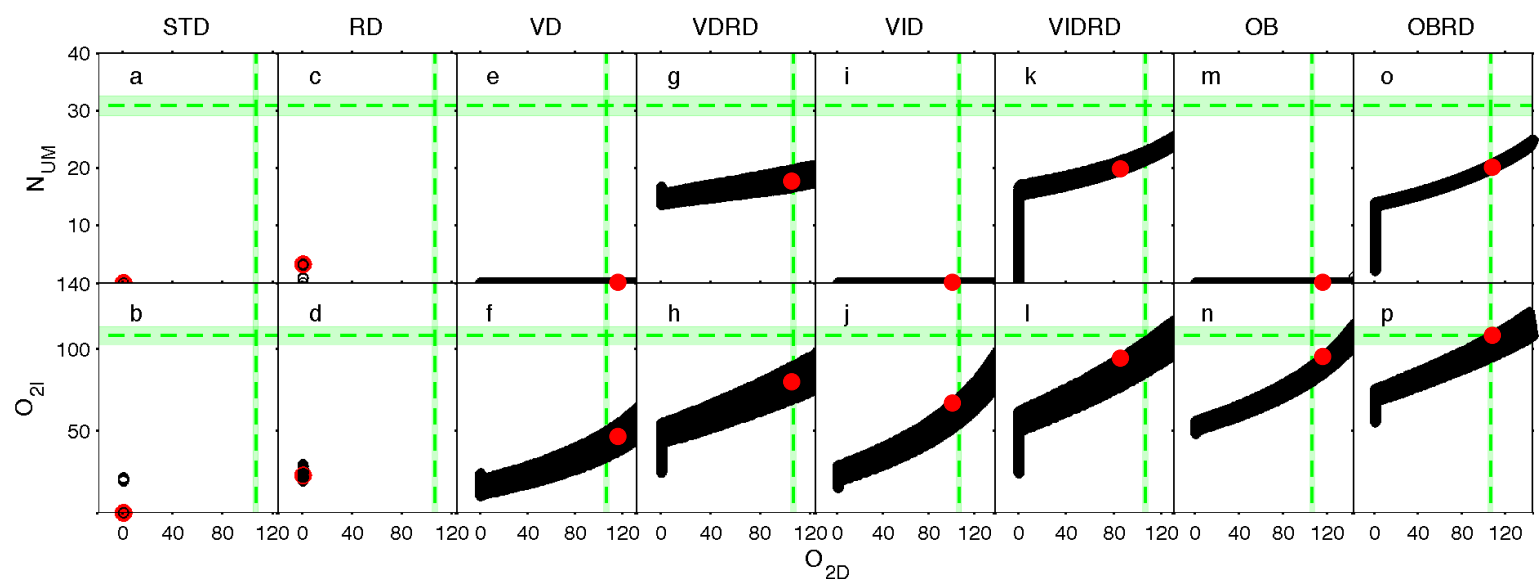

Figure 3. $\mathrm{NO}_{3}^{-}$concentration in the $\mathrm{OMZ}$ and $\mathrm{O}_{2}$ concentration in the $\mathrm{I}$ box for all combinations of $\mathrm{g}_{\mathrm{U}}$ and $\mathrm{g}_{\mathrm{S}}$ resulting in all transport parameters being inside the literature range as given in Table 3. The $x$ axis is the $\mathrm{O}_{2}$ concentration in the $\mathrm{D}$ box. The red dot in each panel is the selected suite of physical transport parameters which fit the biogeochemical data best in each model configuration. The horizontal green dashed lines represent the averages of the WOA2009 data for $\mathrm{NUM}_{\mathrm{UM}}$ and $\mathrm{O}_{2 \mathrm{I}}$, and the vertical green dashed lines denote the averages of the WOA2009 data for $\mathrm{O}_{2 \mathrm{D}}$. The light green shadings show the $95 \%$ confidence intervals of the WOA2009 data. 


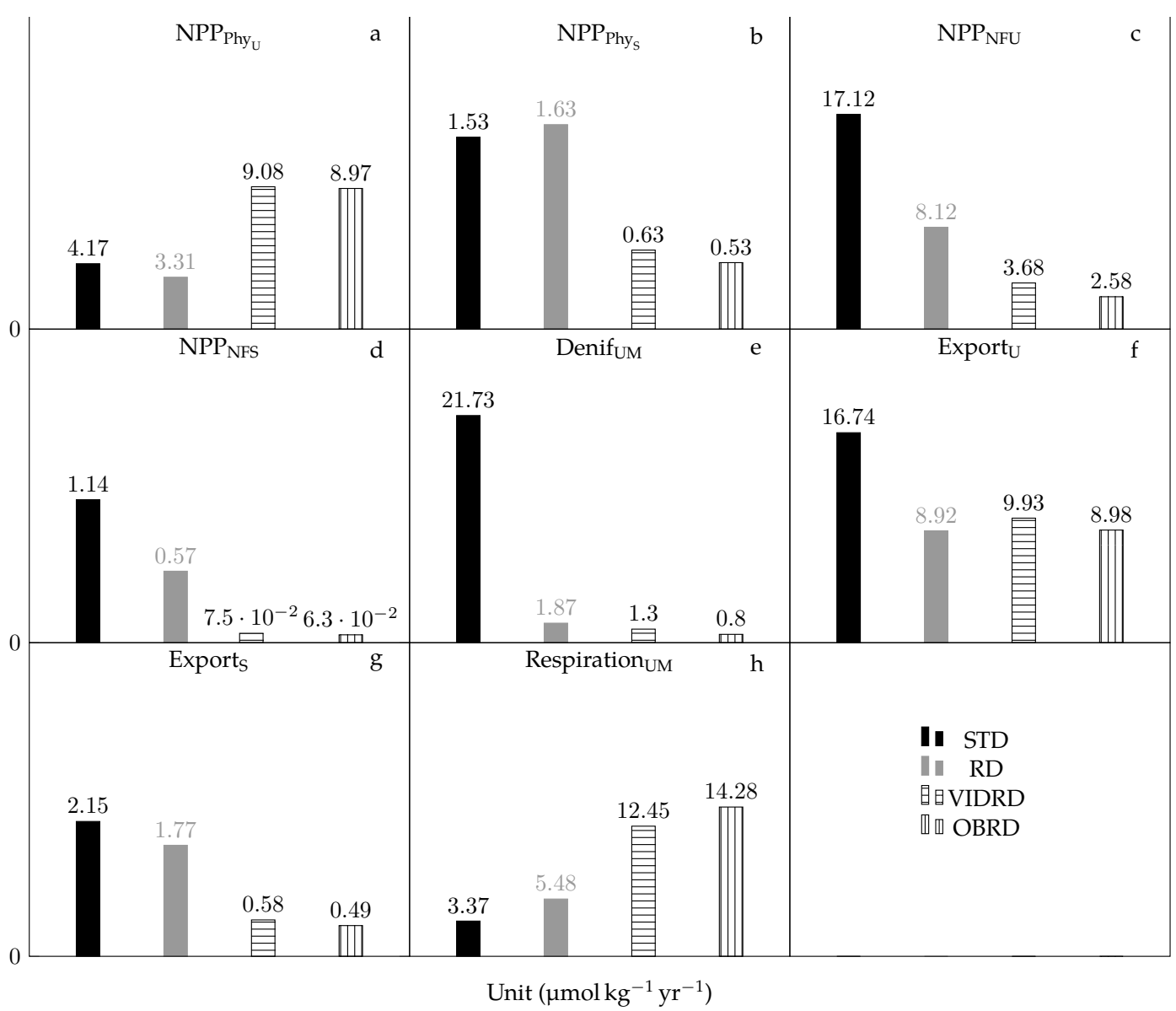

Figure 4. Simulated steady-state biogeochemical fluxes for the main model configurations defined in Tables 5 and $2 . \mathrm{NPP}_{\mathrm{PhyU}}$, NPP $\mathrm{PhyS}_{\mathrm{S}}$, $\mathrm{NPP}_{\mathrm{NFU}}$ and $\mathrm{NPP}_{\mathrm{NFS}}$ represent the net primary production rates of Phy $\mathrm{U}_{\mathrm{U}}$, Phy $\mathrm{S}_{\mathrm{S}}, \mathrm{NF}_{\mathrm{U}}$ and $\mathrm{NF}_{S}$, respectively. Denif $\mathrm{UM}_{\mathrm{M}}$ indicates the nitrogen loss rate by anaerobic remineralization in the UM box. Export $\mathrm{U}_{\mathrm{U}}$ and Export $\mathrm{S}_{\mathrm{S}}$ represent the export production rate out of $\mathrm{U}$ and $\mathrm{S}$. Respiration $_{U M}$ represents aerobic respiration rate in the UM box. Note that all panels are in units of nitrogen except (h), which is in units of $\mathrm{O}_{2}$. Each panel uses a differrent linear scale for the $y$ axis starting at zero.

jacent ocean, it reveals a possible mechanism for preventing $\mathrm{NO}_{3}^{-}$depletion in the OMZ.

While a reduced remineralization rate under suboxic conditions appears to be a prerequisite for maintaining non-zero nitrate in the OMZ (Fig. 3), we find that ventilation of $\mathrm{O}_{2}$ from the lateral subtropical ocean into the model domain is essential for preventing anoxic conditions in the D box. But even ventilation of $\mathrm{O}_{2}$ into both $\mathrm{I}$ and $\mathrm{D}$ boxes fails to prevent $\mathrm{NO}_{3}^{-}$depletion in the UM box in the VID configuration (Fig. 3i). After reducing the denitrification rate in the OMZ, which is the configuration denoted as VIDRD, $\mathrm{NO}_{3}^{-}$depletion is prevented (bars with horizontal lines in Fig. 2). Compared to the $\mathrm{RD}$ configuration, $\mathrm{NO}_{3}^{-}$concentration in the $\mathrm{UM}$ box is in a realistic range $\left(15-40 \mu \mathrm{mol} \mathrm{kg}^{-1}\right)$ for the OMZ, and $\mathrm{O}_{2}$ concentrations in the $\mathrm{I}$ and $\mathrm{D}$ boxes are also closer to the WOA2009 data, but still about 15.0 and $22.7 \%$ lower than the observations (blue dashed lines in Fig. 2).

In the OBRD configuration, nutrients are exchanged in addition to $\mathrm{O}_{2}$ between the subtropical ocean and the $\mathrm{I}$ and $\mathrm{D}$ boxes, together with reducing the denitrification rate under suboxic conditions. $\mathrm{N}_{U M}$ depletion is prevented and $\mathrm{N}_{U M}$ approaches a concentration of $20 \mu \mathrm{mol} \mathrm{kg}{ }^{-1}$ at steady state (bars with horizontal lines in Fig. 2). The UM box is suboxic and the $\mathrm{O}_{2}$ concentrations in the $\mathrm{I}$ and $\mathrm{D}$ boxes agree very well with the WOA2009 data (blue dashed lines in Fig. 2). Overall, the tracer distributions simulated by the OBRD configuration agree best with the observations.

In the sensitivity configuration $\mathrm{OB}$, where only nutrients are exchanged in addition to $\mathrm{O}_{2}$ between the subtropical ocean and the I and D boxes, nitrate is still exhausted in the OMZ (Fig. 3m).

\subsection{Biogeochemical fluxes}

For the biogeochemical fluxes, we focus on the STD, RD, VIDRD and OBRD configurations (configurations in bold in Table 5), since they show most clearly the mechanisms responsible for preventing $\mathrm{NO}_{3}^{-}$depletion in the OMZ (Fig. 4). 
Denitrification rates are much higher in the STD than in the RD configuration (black and grey bars in Fig. 4, respectively), even though the physical parameters are the same in the two configurations, leading to nitrate exhaustion in the UM box of the STD but not in the RD configuration. In both VIDRD and OBRD configurations, $\mathrm{NO}_{3}^{-}$depletion is prevented (bars with horizontal and vertical lines in Fig. 2e). Denitrification is weaker in the OBRD than in the VIDRD configuration (bars with horizontal lines in Fig. 4), even though the physical parameters are the same in both, keeping more $\mathrm{NO}_{3}^{-}$in the UM-box in the OBRD configuration. Aerobic respiration in the UM box continues even when the $\mathrm{UM}$ box is anoxic. It consumes all $\mathrm{O}_{2}$ entering the $\mathrm{UM}$ box via the various physical transport processes and thereby oxidizes about $8.7,64,85$ and $92 \%$ of the organic matter remineralized (denitrification + aerobic respiration) in the UM box in all four configurations, STD, RD, VIDRD and OBRD, respectively. Aerobic respiration is increased in the OBRD configuration compared with the VIDRD configuration $(92 \%$ vs. $85 \%)$ at the expense of denitrification.

Compared with the VIDRD configuration, total $\mathrm{PO}_{4}^{3-}$ in the model domain decreases by about $28 \%$ in the OBRD configuration at steady state, and the net $\mathrm{PO}_{4}^{3-}$ flux out of the I box and the corresponding net flux of $\mathrm{PO}_{4}^{3-}$ from the subtropical ocean into the D box causes a $9.6 \%$ decrease in organic matter exported into the UM box. This explains why $\mathrm{NO}_{3}^{-}$concentrations in the $\mathrm{OMZ}$ and $\mathrm{O}_{2}$ concentrations in the I and D boxes are slightly higher (bars with vertical lines in Fig. 2). Restricting, in a hypothetical sensitivity experiment, exchange with the subtropical oligotrophic ocean to $\mathrm{NO}_{3}^{-}$and $\mathrm{O}_{2}$ does not result in higher $\mathrm{O}_{2}$ concentrations in the $\mathrm{I}$ and $\mathrm{D}$ boxes, because $\mathrm{PO}_{4}^{3-}$ is conserved and export production does not change substantially. Restricting, on the other hand, exchange to $\mathrm{PO}_{4}^{3-}$ and $\mathrm{O}_{2}$ depresses production and organic matter decomposition by almost the same amount as in the model run that exchanges $\mathrm{NO}_{3}^{-}, \mathrm{PO}_{4}^{3-}$ and $\mathrm{O}_{2}$, and succeeds in driving $\mathrm{O}_{2 \mathrm{I}}$ and $\mathrm{O}_{2 \mathrm{D}}$ concentrations closer to the observations (not shown). Thus, opening the model boundary to $\mathrm{PO}_{4}^{3-}$ and $\mathrm{O}_{2}$ helps to improve the model results with respect to those of the VIDRD configuration that do not exchange $\mathrm{PO}_{4}^{3-}$ across the southern boundary.

\subsection{Model sensitivity}

In sensitivity experiments of the OBRD configurations, designed to elucidate the importance of the influence of the subtropical ocean on the model domain, we reduce the mixing rates $\left(K_{\mathrm{H}}\right)$ of $\mathrm{O}_{2}, \mathrm{NO}_{3}^{-}$and $\mathrm{PO}_{4}^{3-}$ across the southern boundary in different combinations (two of them are shown in Fig. 5). Total net primary production (NPP) is the same when varying the mixing rate of either only $\mathrm{O}_{2}$ or $\mathrm{O}_{2}$ together with $\mathrm{NO}_{3}^{-}$, as long as the $\mathrm{PO}_{4}^{3-}$ exchange rate with the subtropical ocean remains unchanged (dotted lines in Fig. 5b). The reason is that changes in nitrate exchange with the subtropical ocean are compensated for by changes in denitrifica-

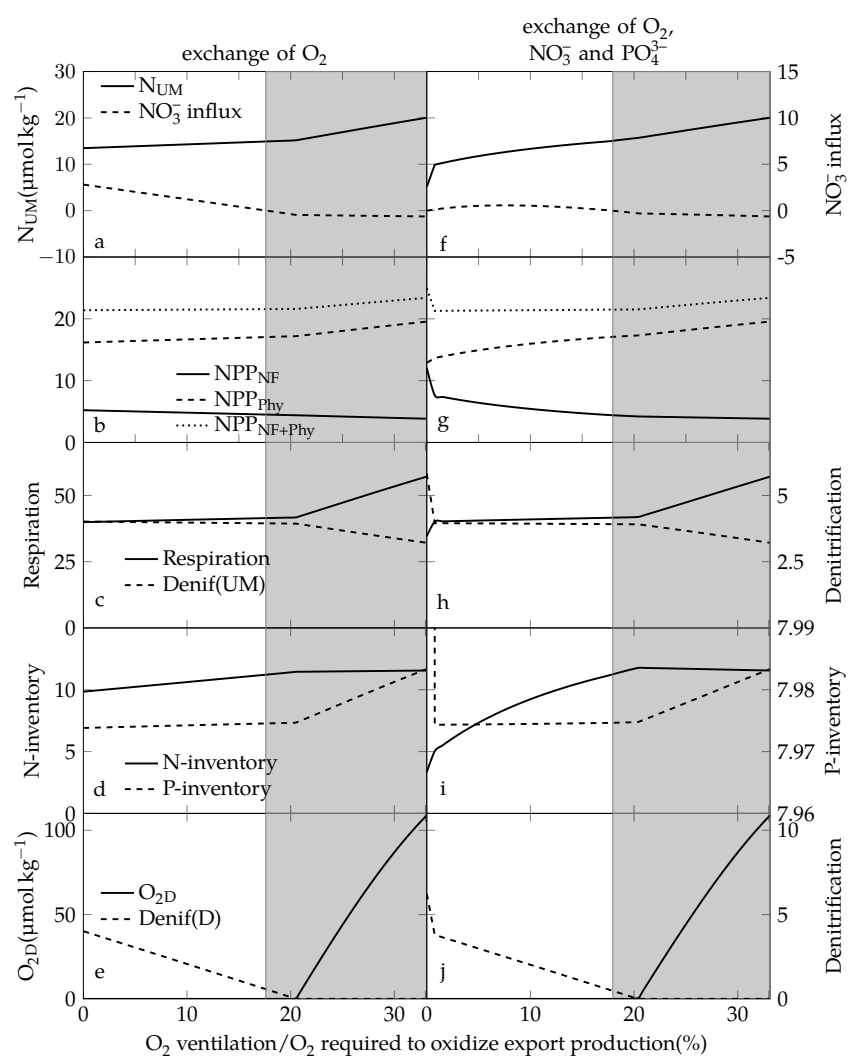

Figure 5. Dependence of biogeochemical processes on the exchange of $\mathrm{O}_{2}, \mathrm{NO}_{3}^{-}$and $\mathrm{PO}_{4}^{3-}$ with the subtropical ocean through the southern boundaries of the $\mathrm{I}$ and $\mathrm{D}$ boxes. The $x$ axes indicate the contribution of $\mathrm{O}_{2}$ supplied from the subtropical ocean relative to that required to oxidize all export production from the surface ocean (boxes $\mathrm{U}$ and $\mathrm{S}$ ). (a-e) only $\mathrm{O}_{2}$ exchanged through the southern boundaries is reduced; $(\mathbf{f}-\mathbf{j})$ exchange of $\mathrm{O}_{2}, \mathrm{NO}_{3}^{-}$and $\mathrm{PO}_{4}^{3-}$ is reduced. $\mathrm{N}_{\mathrm{UM}}$ is $\mathrm{NO}_{3}^{-}$concentration in the $\mathrm{UM}$ box and $\mathrm{NO}_{3}^{-}$influx is the $\mathrm{NO}_{3}^{-}$flux through the southern boundary (positive into model domain). $\mathrm{NPP}_{\mathrm{Phy}}, \mathrm{NPP}_{\mathrm{NF}}$ and $\mathrm{NPP}_{\mathrm{NF}+\mathrm{Phy}}$ are net primary production by ordinary phytoplankton, nitrogen fixers, and the sum of both in the surface ocean. Respiration and Denif (UM) represent $\mathrm{O}_{2}$ consumption by aerobic remineralization and $\mathrm{NO}_{3}^{-}$removal by anaerobic remineralization, respectively, in the UM box. $\mathrm{N}$-inventory and P-inventory are the total nitrogen and phosphorus inventories in the model domain, including all organic and inorganic species. $\mathrm{O}_{2 \mathrm{D}}$ and Denif (D) represent $\mathrm{O}_{2}$ concentration and $\mathrm{NO}_{3}^{-}$ removal by anaerobic remineralization in the $\mathrm{D}$ box. Units of all variables are $10^{11} \mu \mathrm{mol} \mathrm{yr}^{-1} \mathrm{~m}^{-1}$ except for $\mathrm{N}_{U M}$ and $\mathrm{O}_{2 \mathrm{D}}$, which are given in $\mu \mathrm{mol} \mathrm{kg}-1$, and $\mathrm{N}$-inventory and $\mathrm{P}$-inventory, which are $10^{11} \mu \mathrm{mol} \mathrm{m}{ }^{-1}$. The shaded area denotes the parameter range for which the model domain is a net source of $\mathrm{NO}_{3}^{-}$.

tion and nitrogen fixation. This implies that NPP is, at steady state, determined only by phosphate availability. Once the total NPP of NF and Phy is determined by $\mathrm{PO}_{4}^{3-}$ supply, aerobic respiration will increase with increasing $\mathrm{O}_{2}$ supply, while anaerobic remineralization will decrease (solid and dashed lines in Fig. 5c). Comparing simulations that vary the mix- 


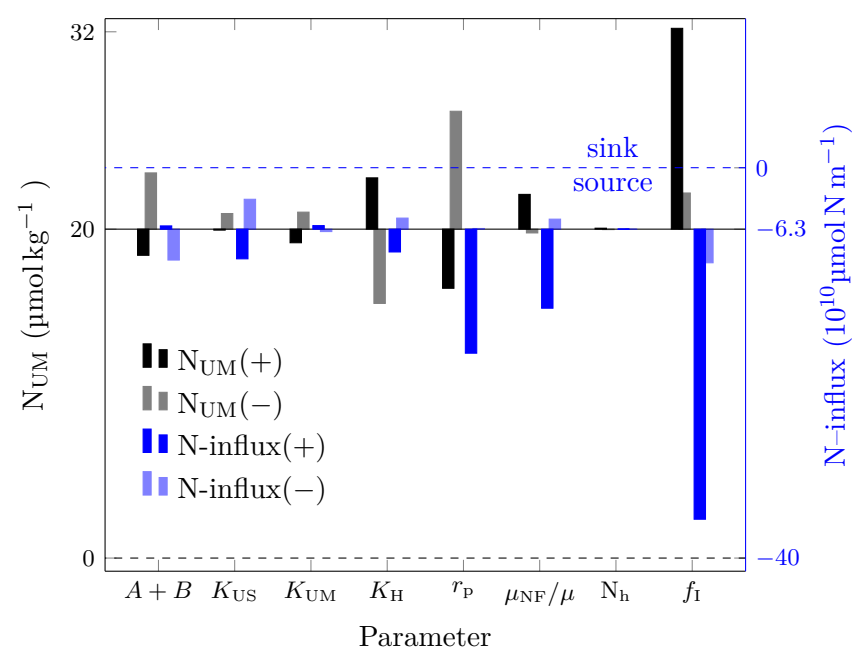

Figure 6. Sensitivity of $\mathrm{NO}_{3}^{-}$concentration in the $\mathrm{OMZ}\left(\mathrm{N}_{U M}\right)$ and the net $\mathrm{NO}_{3}^{-}$flux out of the model domain to variations of the individual parameters describing ocean transport and biogeochemical processes (see Tables 2, 3 and Fig. 1 for a description of the parameters). Black and blue bars represent changes in $\mathrm{N}_{U M}$ and $\mathrm{N}$ influx, respectively. "+" and "-" indicate the response to increased and decreased parameters. Physical circulation parameters are varied by $\pm 50 \%$. $r_{\mathrm{P}}$ is varied between 12 and $20 . \mu_{\mathrm{NF}} / \mu$ is varied between $1 / 4$ and $1 / 2 . \mathrm{N}_{\mathrm{h}}$ varies between 0.3 and $0.9 \mu \mathrm{mol} \mathrm{kg}-1$. For $f_{\mathrm{i}}$, "+ " indicates $f_{\mathrm{U}}=f_{\mathrm{S}}=60 \%$ and $f_{\mathrm{UM}}=f_{\mathrm{I}}=30 \%$, and "-" means $40 \%$ and $50 \%$, respectively.

ing rate of $\mathrm{O}_{2}$ together with that of $\mathrm{PO}_{4}^{3-}$, with simulations that vary the mixing rate of $\mathrm{O}_{2}$ together with that of $\mathrm{NO}_{3}^{-}$ and $\mathrm{PO}_{4}^{3-}$ (dotted lines in Fig. 5g) reveals that the combined NPP of Phy and NF decreases with decreasing $\mathrm{PO}_{4}^{3-}$ inventory at low mixing rates and increases with increasing $\mathrm{PO}_{4}^{3-}$ inventory at high mixing rates, irrespective of $\mathrm{NO}_{3}^{-}$mixing rate.

It turns out that $\mathrm{NO}_{3}^{-}$depletion in the $\mathrm{OMZ}$ is prevented in the four sensitivity experiments of Fig. 5 no matter how much $\mathrm{O}_{2}$ is supplied from the subtropical ocean into the model domain. But anoxia in the D box can only be prevented if the external $\mathrm{O}_{2}$ supply can oxidize more than about $20 \%$ export production in the model domain (solid lines in Fig. $5 e, j$ ). This ratio can vary according to the size of $S$ box. It increases for a smaller $\mathrm{S}$ box, because a smaller $\mathrm{S}$ box leads to less downward $\mathrm{O}_{2}$ supply from the surface box into the lower model domain and more lateral ventilation is needed, and vice versa (not shown). These experiments also reveal an interesting link among the $\mathrm{O}_{2}$ supply from the subtropical ocean, the nitrate concentration in the OMZ, and the $\mathrm{NO}_{3}^{-}$flux between the model domain and surrounding ocean. As soon as the $\mathrm{O}_{2}$ supply from the subtropical ocean accounts for about $17.5 \%$ of the respiratory $\mathrm{O}_{2}$ consumption, the model domain turns into a small net source of $\mathrm{NO}_{3}^{-}$ (dashed lines in the first row of Fig. 5). Once anoxia is prevented in the $\mathrm{D}$ box, the nitrate concentration in the $\mathrm{OMZ}$

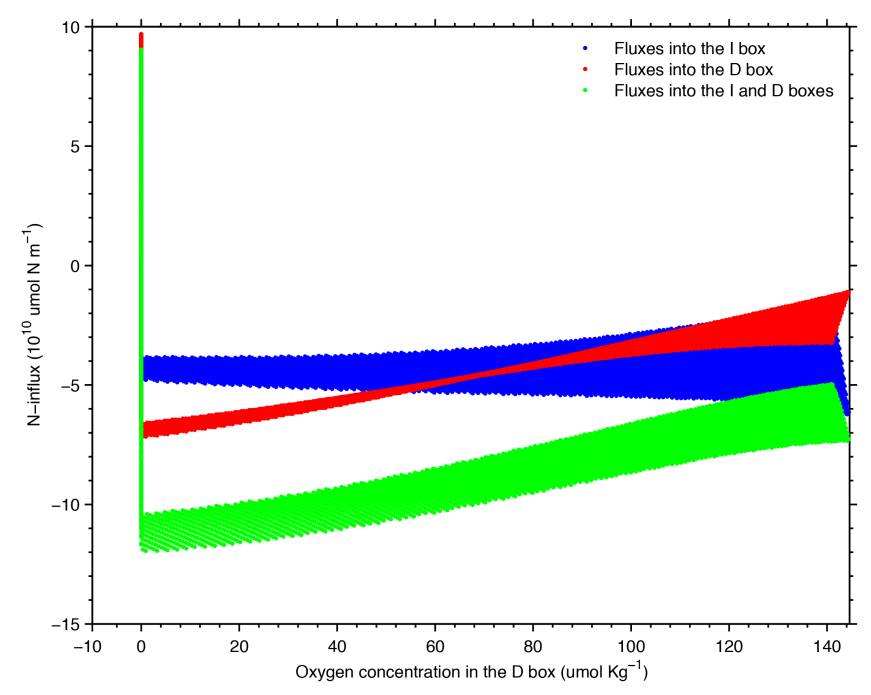

Figure 7. Lateral $\mathrm{NO}_{3}^{-}$input into the model domain of the OBRD configuration as a function of the oxygen concentration in the $\mathrm{D}$ box. "Fluxes into the I box" represents lateral $\mathrm{NO}_{3}^{-}$input into the I box; "fluxes into the $\mathrm{D}$ box" represents lateral $\mathrm{NO}_{3}^{-}$input into the D box; "fluxes into the I and D boxes" is the sum of the above two processes. Note that only the $\mathrm{I}$ and $\mathrm{D}$ boxes can exchange $\mathrm{O}_{2}$ or nutrients with the region outside of the model domain. In this figure, negative values indicate that the model is a $\mathrm{NO}_{3}^{-}$source, and positive values that the model is a $\mathrm{NO}_{3}^{-}$sink instead.

(UM box) increases quite strongly from about $15 \mu \mathrm{mol} \mathrm{kg}{ }^{-1}$ to reach about $20 \mu \mathrm{mol} \mathrm{kg}^{-1}$ at full mixing strength.

The conclusion that the model domain is a small pelagic net $\mathrm{NO}_{3}^{-}$source in the OBRD configuration does not change when individual physical transport parameters vary by up to $\pm 50 \%$ (Fig. 6). Varying biogeochemical parameters also does not affect this conclusion. The finding that the model domain is a net $\mathrm{NO}_{3}^{-}$source is also tenable for all suites of physical transport parameters in the literature range for which the D-box is oxic (Fig. 7).

The oxygen concentrations in the I and D boxes increase in sensitivity model runs with physical parameters calibrated from increased ${ }^{14} \mathrm{C}$ concentrations (lower water mass age, figure not shown). $\mathrm{NO}_{3}^{-}$depletion is prevented in the $\mathrm{OMZ}$ in the OBRD configuration within the range of about $\pm 10 \%$ around the default ventilation intensity (Fig. 8a). The UM box remains anoxic when $\Delta^{14} \mathrm{C}$ is varied within this range, which indicates that this mechanism for preventing $\mathrm{NO}_{3}^{-}$depletion in the $\mathrm{OMZ}$ may be robust against modest changes in the regional ocean circulation patterns. Meanwhile, $\mathrm{NO}_{3}^{-}$ and $\mathrm{O}_{2}$ in the $\mathrm{UM}$ box are quite insensitive to the $\mathrm{O}_{2}$ concentration in the U-box for this configuration (Fig. 8b).

Varying biogeochemical parameters affects individual model predictions but not our main conclusions. The strongest effects are those of varying the $\mathrm{N}: \mathrm{P}$ ratio $r_{\mathrm{p}}$ and the remineralization fractions $\left(f_{\mathrm{U}}, f_{\mathrm{UM}}, f_{\mathrm{S}}\right.$ and $f_{\mathrm{I}}$ ) (Fig. 6). Lowering $r_{\mathrm{p}}$ to 12 increases $\mathrm{N}_{\mathrm{UM}}$ by about $35 \%$, but can- 

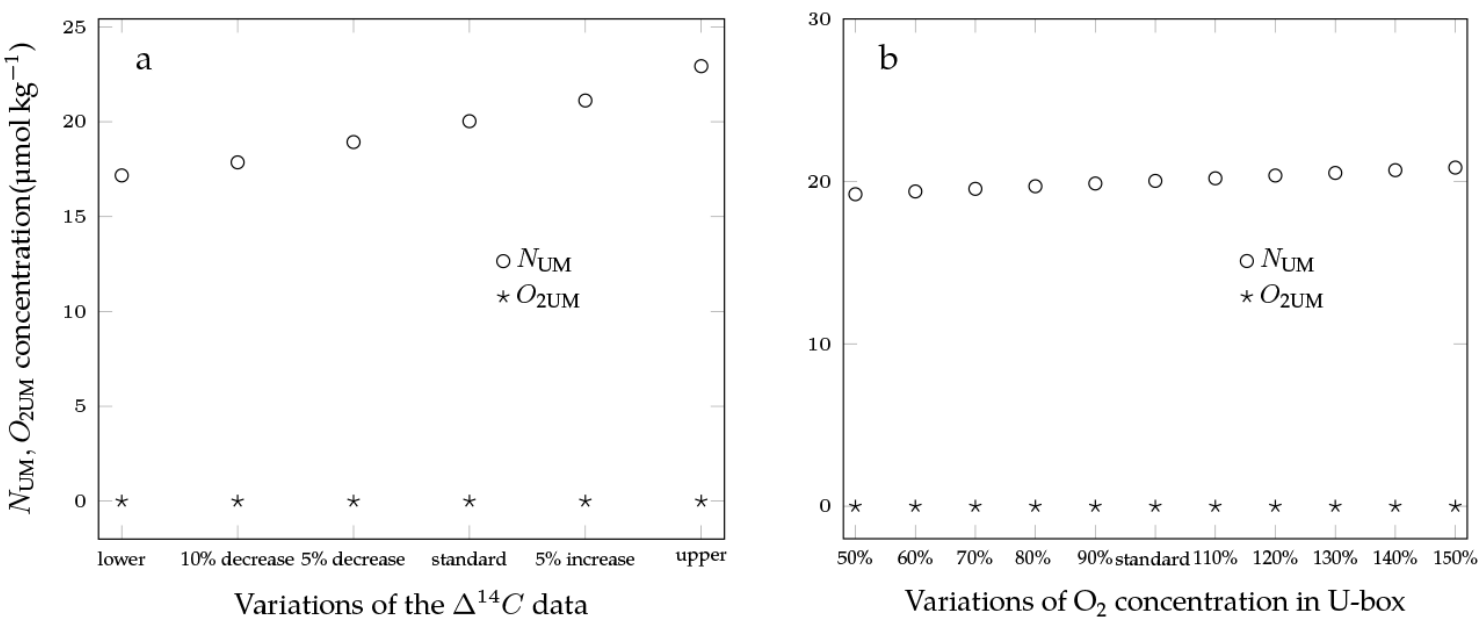

Figure 8. $\mathrm{NO}_{3}^{-}$and $\mathrm{O}_{2}$ concentrations in the OBRD configuration for different physical parameters derived from variations of the $\Delta^{14} \mathrm{C}$ data (a) and $\mathrm{O}_{2}$ concentration in the $\mathrm{U}$ box (b). (a) Decrease and increase mean that $\Delta^{14} \mathrm{C}$ values in all boxes are reduced or increased simultaneously. (b) Values of the $x$ axis denote the variations of $\mathrm{O}_{2}$ concentration in the $\mathrm{U}$ box relative to the standard. The standard run in each figure is the OBRD configuration with physical parameters defined in Table 2.

Table 6. Denitrification comparison with model-based and observational estimates.

\begin{tabular}{lc}
\hline Data/models & $\begin{array}{c}\text { Denitrification } \\
\left(\mathrm{TgN} \mathrm{yr}^{-1}\right)\end{array}$ \\
\hline OBRD configuration & $5.0^{\mathrm{c}}$ \\
Kalvelage et al. (2013) $^{\mathrm{a}}$ & $10.2^{\mathrm{c}}$ \\
T. DeVries et al. (2013, pers. comm.) $^{\mathrm{b}}$ & $7.0 \pm 2.0^{\mathrm{c}}$ \\
Bianchi et al. (2012) $^{\mathrm{a}}$ & $17.6^{\mathrm{d}}$ \\
C. Somes et al. (2010, pers. comm. $^{\mathrm{b}}$ & $5.8^{\mathrm{c}}$ \\
Mills and Arrigo (2010) $^{\mathrm{b}}$ & $1.9^{\mathrm{c}, *}$ \\
\hline
\end{tabular}

${ }^{a}$ Observational estimate; ${ }^{b}$ model results; ${ }^{c}$ ETSP; ${ }^{d}$ entire South Pacific; $*$ OMZ value extrapolated to the UM box of our model.

not change the strength of our model domain as a net $\mathrm{NO}_{3}^{-}$ source. Increasing $r_{\mathrm{p}}$ to 20 decreases $\mathrm{N}_{\mathrm{UM}}$ by about $18 \%$, but triples the strength of our model domain as a $\mathrm{NO}_{3}^{-}$source. However, observations indicate that $r_{\mathrm{p}}$ for the ETSP is more likely to be higher than lower compared to the Redfield N : $\mathrm{P}$ ratio of 16 (Franz et al., 2012). Increasing the maximum growth rate of NF, $\mu_{\mathrm{NF}}$, to $1 / 2 \mu$, the maximum growth rate of Phy, results in higher $\mathrm{N}_{\mathrm{UM}}$ concentrations and our model domain being a larger $\mathrm{NO}_{3}^{-}$source. Intuitively, decreasing $\mu_{\mathrm{NF}}$ to $1 / 4 \mu$ results in lower $\mathrm{N}_{\mathrm{UM}}$ concentrations and our model domain becoming a smaller $\mathrm{NO}_{3}^{-}$source. Varying the $\mathrm{NO}_{3}^{-}$half saturation constant, $\mathrm{N}_{\mathrm{h}}$, results in virtually unchanged results. $\mathrm{N}_{\mathrm{UM}}$ increases when changing remineralization fractions in the intermediate boxes $\left(f_{\mathrm{UM}}\right.$ and $\left.f_{\mathrm{I}}\right)$ from 70 to 50 and $30 \%$, respectively, effectively lowering export production via lowering the export ratio. Nevertheless, the qualitative behaviour of the model remains the same in these sensitivity experiments.

\section{Discussion and conclusions}

Nitrogen is often considered to be the primary limiting nutrient in marine upwelling regions with OMZs (Cline and Richards, 1972; Codispoti and Christensen, 1985; Morrison et al., 1998; Voss et al., 2001), where denitrification rates can be high and are generally thought to cause a major loss of $\mathrm{NO}_{3}^{-}$from the world's oceans. The nitrogen deficit is commonly assumed to stimulate $\mathrm{N}_{2}$ fixation, both in observational estimates of $\mathrm{N}_{2}$ fixation (Deutsch et al., 2007; Monteiro et al., 2010) and in current descriptions of $\mathrm{N}_{2}$ fixation in biogeochemical models (Moore and Doney, 2007; Schmitther et al., 2008). However, if $\mathrm{N}_{2}$ fixation is tightly linked to nitrogen loss processes, denitrification of organic matter derived from $\mathrm{N}_{2}$ fixation can consume more nitrogen than was fixed via $\mathrm{N}_{2}$ fixation and thereby lead to a vicious cycle of runaway nitrogen loss (Landolfi et al., 2013). This has been found to lead to total depletion of $\mathrm{NO}_{3}^{-}$in the $\mathrm{OMZ}$ of box models (Canfield, 2006) and global biogeochemical circulation models (Moore and Doney, 2007; Schmittner et al., 2008). For our fully prognostic 5-box model, we have identified the mechanisms capable of arresting the runaway nitrogen loss that can result from a close coupling of nitrogen fixation and denitrification (Landolfi et al., 2013) and maintaining realistic non-zero $\mathrm{NO}_{3}^{-}$concentrations in open-ocean OMZs of the ETSP: reduced $\mathrm{NO}_{3}^{-}$consumption by denitrification owing to slower remineralization under suboxic compared to oxic conditions, coupled with lateral ventilation of oxygen and, to some extent, nutrients with the subtropics.

In this work, the model configuration with reduced denitrification rate, and lateral ventilation and nutrient exchange (OBRD configuration) performs best with respect to the observations, whereas reduced rates of denitrification alone 
lead to unrealistic $\mathrm{O}_{2}$ depletion in the deep waters, and reduced rates of denitrification combined with only $\mathrm{O}_{2}$ ventilation in the $\mathrm{D}$, or both $\mathrm{I}$ and $\mathrm{D}$ boxes still underestimate the WOA2009 data for $\mathrm{O}_{2}$ in the $\mathrm{I}$ and $\mathrm{D}$ boxes. By allowing for exchange of $\mathrm{O}_{2}$ and nutrients with the subtropical ocean in the OBRD configuration, the delicate balance between sufficient $\mathrm{O}_{2}$ supply required for maintaining high levels of aerobic respiration and sufficient $\mathrm{PO}_{4}^{3-}$ loss through the open boundary appears fulfilled. Compared with other box models (Shaffer and Sarmiento, 1995; Tyrrell, 1999; Deutsch et al., 2004; Canfield, 2006; Mills and Arrigo, 2010; Eugster and Gruber, 2012; DeVries et al., 2012), the box model we use here explicitly employs both a reduced-denitrification rate and an open boundary condition, which seems to be a prerequisite for the ability to simulate realistic nitrate conditions in the $\mathrm{OMZ}$ and oxygen concentrations in the adjacent ocean.

The $\mathrm{NO}_{3}^{-}$loss by denitrification in the OMZ of the OBRD configuration is compared with that of other model-based and observational estimates in Table 6. Our simulated denitrification is consistent with the results of Somes et al. (2010) and DeVries et al. (2013) for the ETSP, lower than the estimate of Bianchi et al. (2012) and Kalvelage et al. (2013), but higher than that of Mills and Arrigo (2010). However, the estimated denitrification by Bianchi et al. (2012) represents that of the entire South Pacific but not only the ETSP. The Kalvelage et al. (2013) model has much higher fixed-N influx into the OMZ via physical transport than our model, which could compensate for their more intense $\mathrm{NO}_{3}^{-}$loss by denitrification.

Phosphate turns out to be the ultimate limiting nutrient in our model (Fig. 5), and hence determines the nitrogen content of the OMZ. This strong control of the $\mathrm{N}$ cycle by phosphate is similar to the findings of previous models (e.g. Lenton and Watson, 2000; Canfield, 2006), where the occurrence and extent of oceanic anoxia was also tightly linked to phosphate supply. These studies explicitly assumed that $\mathrm{N}_{2}$ fixation acts to restore surface-oceanic dissolved inorganic $\mathrm{N}$ : P ratio towards the Redfield ratio. By contrast, we do not prescribe the effect of nitrogen fixation on surface inorganic nutrients, and the finding of phosphate as the ultimate limiting nutrient is obtained regardless of whether NF responds directly to the $\mathrm{N}: \mathrm{P}$ ratio in the surface ocean or whether NF is inhibited by the presence of $\mathrm{NO}_{3}^{-}$(see Appendix B).

Even though our model indicates only a weak dependence of simulated $\mathrm{NO}_{3}^{-}$concentrations in the $\mathrm{OMZ}$ on the lateral $\mathrm{O}_{2}$ supply from the subtropical ocean, $\mathrm{O}_{2}$ depletion in the adjacent ocean can be prevented only when the $\mathrm{O}_{2}$ supply from the subtropical ocean accounts for more than $20 \%$ of the $\mathrm{O}_{2}$ required to oxidize export production from the surface ocean of our model domain ( $\mathrm{U}$ and $\mathrm{S}$ boxes). This value only varies between about 17 and $23 \%$, when the size of the $\mathrm{S}$ box varies by $\pm 50 \%$, indicating that our above conclusion is rather insensitive to our choice of model domain. The $\mathrm{O}_{2}$ supply from the subtropical ocean might be also linked to the balance of the regional fixed-N cycle. In the most re- alistic (OBRD) configuration, the balance of water-column denitrification and nitrogen fixation is tightly linked to the nitrate concentration in the OMZ: if the model domain acts as a sink for $\mathrm{NO}_{3}^{-}$, nitrate concentrations in the OMZ do not exceed about $15 \mu \mathrm{mol} \mathrm{kg}{ }^{-1}$, i.e. the lower limit of current observations, 15 to $40 \mu \mathrm{mol} \mathrm{kg}^{-1}$ (Codispoti and Richards, 1976; Codispoti and Packard, 1980; Morrison et al., 1998; Voss et al., 2001). Nitrate concentrations close to those commonly found in OMZs are predicted only when nitrogen fixation exceeds water-column denitrification and the ocean basin containing the $\mathrm{OMZ}$ becomes a net source of $\mathrm{NO}_{3}^{-}$(Fig. 5a, f).

There are no specific data or model results focusing on the water-column nitrogen balance of the ETSP. Our simulations using a parameterization where nitrogen fixation is inhibited by the presence of nitrate yield very similar results, only with slightly reduced nitrogen fixation resulting in a somewhat reduced (by $\leq 15 \%$ ) nitrogen source for strong enough lateral oxygen supply. Ganachaud and Wunsch (2002) estimated a net northward $\mathrm{NO}_{3}$ transport of $270 \pm 170 \mathrm{kmol} \mathrm{s}^{-1}\left(119.2 \pm 75.1 \mathrm{Tg} \mathrm{N} \mathrm{yr}^{-1}\right)$ across $17^{\circ} \mathrm{S}$ into the ETSP in a geostrophic inverse box model, which indicates that the ETSP is a net nitrogen sink, but their estimate included benthic denitrification, which is not accounted for in our current analysis. In a model-guided analysis, DeVries et al. (2012) predicted water-column denitrification rates of $21-33 \mathrm{Tg} \mathrm{Nyr}^{-1}$ by simulating the distribution of observed dissolved $\mathrm{N}_{2}$ gas produced by denitrifying bacteria. From an ocean circulation-biogeochemical modelbased analysis of nutrient concentrations and transport rates, Deutsch et al. (2007) estimated nitrogen fixation rates in the Pacific Ocean of about $95 \mathrm{Tg} \mathrm{N} \mathrm{yr}^{-1}$, half of which was speculated to occur in the ETSP. From these estimates, we cannot rule out that the water column of the ETSP is a net source of $\mathrm{NO}_{3}^{-}$, which would be consistent with our results obtained in the OBRD configuration. More recently, Eugster and Gruber (2012) probabilistically estimated nitrogen fixation and water-column and benthic denitrification separately in their box model, which appears to be consistent with our results as their results also indicate that the water column of the IndoPacific is a large fixed-N source.

Based on our model results, we conclude that reduced $\mathrm{NO}_{3}^{-}$consumption by denitrification owing to slower remineralization under suboxic conditions together with lateral transport is essential to arrest the vicious cycle of runaway fixed-N loss in the OMZ. More research is needed to better constrain the model parameters, in particular the upwelling transport and the difference between the organic matter remineralization rate via aerobic respiration and anaerobic denitrification. 


\section{Appendix A}

Physical transports of a tracer $X$ among the boxes U, UM, S, $\mathrm{I}$ and $\mathrm{D}$ are defined for the STD configuration as follows:

$$
\begin{aligned}
\operatorname{Transport}\left(X_{\mathrm{U}}\right) & =\left(X_{\mathrm{UM}}-X_{\mathrm{U}}\right)\left(A+B+K_{\mathrm{US}}\right) \cdot L_{\mathrm{U}} \\
\operatorname{Transport}\left(X_{\mathrm{UM}}\right) & =\left[A X_{\mathrm{D}}+B X_{\mathrm{I}}-X_{\mathrm{UM}}(A+B)\right. \\
& \left.+K_{\mathrm{US}}\left(X_{\mathrm{U}}-X_{\mathrm{UM}}\right)\right] \cdot L_{\mathrm{U}} \\
& +K_{\mathrm{UM}}\left(X_{\mathrm{D}}-X_{\mathrm{UM}}\right) \cdot L_{\mathrm{U}} \\
& +K_{\mathrm{H}}\left(X_{\mathrm{I}}-X_{\mathrm{UM}}\right) \cdot H_{\mathrm{UM}} \\
\operatorname{Transport}\left(X_{\mathrm{S}}\right) & =(A+B)\left(X_{\mathrm{U}}-X_{\mathrm{S}}\right) \cdot L_{\mathrm{U}} \\
& +K_{\mathrm{US}}\left(X_{\mathrm{I}}-X_{\mathrm{S}}\right) \cdot L_{\mathrm{S}} \\
\operatorname{Transport}\left(X_{\mathrm{I}}\right) & =(A+B)\left(X_{\mathrm{S}}-X_{\mathrm{I}}\right) \cdot L_{\mathrm{U}} \\
& +K_{\mathrm{H}}\left(X_{\mathrm{UM}}-X_{\mathrm{I}}\right) \cdot H_{\mathrm{UM}} \\
& +K_{\mathrm{US}}\left(X_{\mathrm{S}}-X_{\mathrm{I}}\right) \cdot L_{\mathrm{S}} \\
& +K_{\mathrm{UM}}\left(X_{\mathrm{D}}-X_{\mathrm{I}}\right) \cdot L_{\mathrm{S}} \\
\operatorname{Transport}\left(X_{\mathrm{D}}\right) & =A\left(X_{\mathrm{I}}-X_{\mathrm{D}}\right) \cdot L_{\mathrm{U}} \\
& +K_{\mathrm{UM}}\left(X_{\mathrm{UM}}-X_{\mathrm{D}}\right) \cdot L_{\mathrm{U}} \\
& +K_{\mathrm{UM}}\left(X_{\mathrm{I}}-X_{\mathrm{D}}\right) \cdot L_{\mathrm{S}} .
\end{aligned}
$$

For the VD, VDRD, VID, VIDRD, OB and OBRD configurations, Eqs. (A4) and (A5) are modified to read:

$$
\begin{aligned}
\operatorname{Transport}\left(X_{\mathrm{I}}\right) & =(A+B)\left(X_{\mathrm{S}}-X_{\mathrm{I}}\right) \cdot L_{\mathrm{U}} \\
& +K_{\mathrm{H}}\left(X_{\mathrm{UM}}-X_{\mathrm{I}}\right) \cdot H_{\mathrm{UM}} \\
& +K_{\mathrm{US}}\left(X_{\mathrm{S}}-X_{\mathrm{I}}\right) \cdot L_{\mathrm{S}} \\
& +K_{\mathrm{UM}}\left(X_{\mathrm{D}}-X_{\mathrm{I}}\right) \cdot L_{\mathrm{S}} \\
& +K_{\mathrm{H}}\left(X_{\mathrm{SI}}-X_{\mathrm{I}}\right) \cdot H_{\mathrm{UM}}
\end{aligned}
$$

$$
\begin{aligned}
\operatorname{Transport}\left(X_{\mathrm{D}}\right)= & A\left(X_{\mathrm{I}}-X_{\mathrm{D}}\right) \cdot L_{\mathrm{U}}+K_{\mathrm{UM}}\left(X_{\mathrm{UM}}-X_{\mathrm{D}}\right) \\
& \cdot L_{\mathrm{U}}+K_{\mathrm{UM}}\left(X_{\mathrm{I}}-X_{\mathrm{D}}\right) \cdot L_{\mathrm{S}} \\
+ & K_{\mathrm{H}}\left(X_{\mathrm{SD}}-X_{\mathrm{D}}\right) \cdot H_{\mathrm{D}}
\end{aligned}
$$

The transport equations (Eqs. A1, A3) are modified for Phy and NF because Phy and NF are assumed to be capable of regulating their buoyancy and exist only in $\mathrm{U}$ and $\mathrm{S}$ without being transported vertically between the $\mathrm{U}$ and $\mathrm{UM}$ or the $\mathrm{S}$ and I boxes.

\section{Appendix B}

It is well known from laboratory studies that diazotrophic phytoplankton can also utilize nitrate for growth, denoted as facultative $\mathrm{N}_{2}$-fixation (e.g. Holl and Montoya, 2005). Schmittner et al. (2008) introduced a formulation where nitrogen fixers preferentially use nitrate when available and cover only the residual nitrogen demand via $\mathrm{N}_{2}$ fixation. In order to examine the behaviour of our model when nitrogen fixers (NF) preferentially use nitrate, nitrogen fixation is separated from diazotroph growth, as in Schmittner et al. (2008):
Nitrogen-fixation ${ }_{i}=\left(1-\frac{\mathrm{N}}{\mathrm{N}+\mathrm{N}_{\mathrm{h}}}\right) \cdot \mathrm{NPP}^{\mathrm{NF}_{i}}$

$$
i \in[\mathrm{U}, \mathrm{S}]
$$

and Eq. (7) was modified to accommodate the additional nitrate uptake by NF as follows:

$$
\begin{aligned}
\operatorname{SMS}\left(\mathrm{N}_{i}\right)= & \left(-\mathrm{NPP}^{\mathrm{Phy}_{i}}-\left(\mathrm{NPP}^{\mathrm{NF}_{i}}-\text { Nitrogen-fixation }_{i}\right)\right) \\
& \cdot V_{i}+\mathrm{Rem}_{i}^{\mathrm{N}}-\text { Denif }_{i} \\
& i \in[\mathrm{U}, \mathrm{UM}, \mathrm{S}, \mathrm{I}, \mathrm{D}] .
\end{aligned}
$$

After incorporating Eqs. B1 and B2 in our all configurations described in Sect. 2.2, they behave very similarly compared to Fig. 2, except that $\mathrm{Phy}_{\mathrm{U}}$ and $\mathrm{Phy}_{\mathrm{S}}$ concentrations are somewhat lower because nitrogen fixers take up $\mathrm{NO}_{3}^{-}$ as well. Thus, we conclude that our results are robust with respect to assumptions about facultative $\mathrm{N}_{2}$-fixation by diazotrophs.

\section{Appendix C}

The nitrogen cycle in this model includes nitrogen fixation, denitrification, inorganic nitrogen regeneration by remineralization, physical transport of $\mathrm{NO}_{3}^{-}$, and transport of Phy and $\mathrm{NF}$ between the $\mathrm{U}$ and $\mathrm{S}$ boxes. The physical transport process of $\mathrm{NO}_{3}^{-}$is the same as for other tracers. Rem ${ }_{i}^{\mathrm{N}}$ represents nitrogen remineralization in box $i$ with fixed fractions $f_{i}$ of the net primary production in the overlaying surface boxes.

$$
\begin{aligned}
& \operatorname{Rem}_{\mathrm{U}}^{\mathrm{N}}=f_{\mathrm{U}} M\left(\mathrm{Phy}_{\mathrm{U}}+\mathrm{NF}_{\mathrm{U}}\right) \cdot H_{\mathrm{U}} \cdot L_{\mathrm{U}} \\
& \operatorname{Rem}_{\mathrm{UM}}^{\mathrm{N}}=f_{\mathrm{UM}} M\left(\mathrm{Phy}_{\mathrm{U}}+\mathrm{NF}_{\mathrm{U}}\right) \cdot H_{\mathrm{U}} \cdot L_{\mathrm{U}} \\
& \operatorname{Rem}_{\mathrm{S}}^{\mathrm{N}}=f_{\mathrm{S}} M\left(\mathrm{Phy}_{\mathrm{S}}+\mathrm{NF}_{\mathrm{S}}\right) \cdot H_{\mathrm{U}} \cdot L_{\mathrm{S}} \\
& \operatorname{Rem}_{\mathrm{I}}^{\mathrm{N}}=f_{\mathrm{I}} M\left(\mathrm{Phy}_{\mathrm{S}}+\mathrm{NF}_{\mathrm{S}}\right) \cdot H_{\mathrm{U}} \cdot L_{\mathrm{S}} \\
& \operatorname{Rem}_{\mathrm{D}}^{\mathrm{N}}=M\left[\left(1-f_{\mathrm{U}}-f_{\mathrm{UM}}\right)\left(\mathrm{Phy}_{\mathrm{U}}+\mathrm{NF}_{\mathrm{U}}\right) \cdot L_{\mathrm{U}}\right. \\
& \left.\quad+\left(1-f_{\mathrm{S}}-f_{\mathrm{I}}\right)\left(\mathrm{Phy}_{\mathrm{S}}+\mathrm{NF}_{\mathrm{S}}\right) \cdot L_{\mathrm{S}}\right] \cdot H_{\mathrm{U}} .
\end{aligned}
$$

Denitrification (Denif) is the nitrogen loss to $\mathrm{N}_{2}$ when UM, I and $\mathrm{D}$ are anoxic. It is defined as:

$$
\begin{aligned}
\operatorname{Denif}_{i} & =\max \left(\operatorname{Rem}_{i}^{\mathrm{N}}-\frac{\operatorname{Res}_{i}}{r_{\mathrm{a}}}, 0\right) \cdot \frac{r_{\mathrm{c}}}{r_{\mathrm{den}}} \\
i & \in[\mathrm{UM}, \mathrm{I}, \mathrm{D}]
\end{aligned}
$$

with the aerobic respiration term $\operatorname{Res}_{i}$ given below (Eq. C10). In the RD, VDRD, VIDRD and OBRD configurations, the equations for denitrification in the $i$ box and remineralization in $\mathrm{D}$ are given by:

$$
\begin{gathered}
\operatorname{Denif}_{i}=\frac{1}{5} \cdot \max \left(\operatorname{Rem}_{i}^{\mathrm{N}}-\frac{\operatorname{Res}_{i}}{r_{\mathrm{a}}}, 0\right) \cdot \frac{r_{\mathrm{c}}}{r_{\mathrm{den}}} \\
i \in[\mathrm{UM}, \mathrm{I}]
\end{gathered}
$$




$$
\begin{aligned}
\operatorname{Rem}_{\mathrm{D}}^{\mathrm{N}} & =M\left[\left(1-f_{\mathrm{U}}-f_{\mathrm{UM}}\right)\left(\mathrm{Phy}_{\mathrm{U}}+\mathrm{NF}_{\mathrm{U}}\right) \cdot L_{\mathrm{U}}\right. \\
& \left.+\left(1-f_{\mathrm{S}}-f_{\mathrm{I}}\right)\left(\mathrm{Phy}_{\mathrm{S}}+\mathrm{NF}_{\mathrm{S}}\right) \cdot L_{\mathrm{S}}\right] \cdot H_{\mathrm{U}} \\
& +4 \cdot \frac{\text { Denif }_{i} \cdot r_{\mathrm{den}}}{r_{\mathrm{c}}} \quad i \in[\mathrm{UM}, \mathrm{I}]
\end{aligned}
$$

All the organic matter is composed according to the Redfield ratio, i.e. $\mathrm{C}: \mathrm{N}: \mathrm{P}=106: 16: 1$. Rem $_{i}^{\mathrm{P}}$ represents phosphate remineralization in box $i$, which is obtained by dividing $\operatorname{Rem}_{i}^{\mathrm{N}}$ by the Redfield $\mathrm{N}: \mathrm{P}$ ratio, $r_{\mathrm{p}}$ :

$\operatorname{Rem}_{i}^{\mathrm{P}}=\frac{\operatorname{Rem}_{i}^{\mathrm{N}}}{r_{\mathrm{p}}} \quad i \in[\mathrm{U}, \mathrm{S}, \mathrm{UM}, \mathrm{I}, \mathrm{D}]$.

Respiration $\left(\operatorname{Res}_{i}\right)$ is considered in the intermediate and deep ocean. In the presence of sufficient oxygen or when oceanic circulation supplies enough $\mathrm{O}_{2}$, organic matter will be preferentially oxidized by respiration. We use a ratio of $-\mathrm{O}_{2}$ : $\mathrm{N}=170: 16$ during oxic remineralization of organic matter (Anderson and Sarmiento, 1994).

$$
\begin{aligned}
\operatorname{Res}_{i}= & \left\{\begin{array}{lll}
r_{\mathrm{a}} \cdot \operatorname{Rem}_{i}^{\mathrm{N}} & \text { if } & \mathrm{O}_{2 i}>0 \\
\min \left(\operatorname{Transport}\left(\mathrm{O}_{2 i}\right), r_{\mathrm{a}} \cdot \operatorname{Rem}_{i}^{\mathrm{N}}\right) & \text { if } & \mathrm{O}_{2 i}=0
\end{array}\right. \\
i \in[\mathrm{UM}, \mathrm{I}, \mathrm{D}] . &
\end{aligned}
$$

\section{Appendix D}

Transport and SMS terms for $\widehat{{ }^{14} \mathrm{C}}$ constitute a system of 5 linear equations including transport parameters $A, B, K_{\mathrm{US}}$, $K_{\mathrm{UM}}$ and $K_{\mathrm{H}}$, which are inverted from the $\Delta^{14} \mathrm{C}$ values with air-sea $\Delta^{14} \mathrm{C}$ exchange rates $g_{\mathrm{U}}$ and $g_{\mathrm{S}}$ for the $\mathrm{U}$ and $\mathrm{S}$ boxes, respectively as inputs. All possible combinations of values (with a step size of $0.01 \mathrm{~m} \mathrm{yr}^{-1}$ ) for $\mathrm{g}_{U}$ and $\mathrm{g}_{\mathrm{S}}$ are applied to derive the values for transport parameters A, B, $K_{\mathrm{US}}$, $K_{\mathrm{UM}}$ and $K_{\mathrm{H}} . g_{\mathrm{U}}$ and $g_{\mathrm{S}}$ are constrained in a two-step procedure. First, all combinations are determined which result in transport parameters in the literature range in Table 3. Finally, the combination giving the most realistic biogeochemical tracer concentrations (closest to observations) is chosen for the experiments in the main text (Fig. 3). This approach for determining the physical transport parameters is applied to obtain those in Table 2.

\section{Appendix E}

The VD, VDRD, VID and OB configurations are sensitivity configurations that we employ to explore the ability of several mechanisms for preventing nitrogen exhaustion in the OMZ. Even though all of them fail in simulating realistic biogeochemical tracer concentrations compared with observations, they reveal insights into the effects of the respective mechanisms.

The VD configuration, which differs from the STD configuration in supplying additional $\mathrm{O}_{2}$ from the subtropical ocean into the D box, avoids anoxic deep waters, but fails to prevent nitrate exhaustion in the UM box (Fig. 3e, f). The I and D boxes are oxic at steady state, but $\mathrm{NO}_{3}^{-}$is still exhausted by denitrification in the UM box. Comparing the oxygen concentrations of the RD and VD configurations, we conclude that ventilation helps to prevent oxygen depletion in the $\mathrm{D}$ box, but this mechanism alone cannot prevent eventual runaway denitrification in the UM box.

After incorporating reduced denitrification in the VDRD configuration, nitrate depletion is prevented and the I and D boxes are oxic (Fig. $3 \mathrm{~g}, \mathrm{~h}$ ). But the $\mathrm{O}_{2}$ concentration in the I box is about $28 \%$ lower than that of the WOA2009 data, which indicates that $\mathrm{O}_{2}$ supply into the D-box only may not be sufficient to ventilate the model domain.

The VID configuration, which is modified from the VD configuration by including $\mathrm{O}_{2}$ ventilation into the $\mathrm{I}$ box, fails to prevent $\mathrm{NO}_{3}^{-}$depletion by denitrification in the $\mathrm{OMZ}$ (Fig. 3i, j).

In the OB configuration, nutrients are exchanged in addition to $\mathrm{O}_{2}$ between the subtropical ocean and the $\mathrm{I}$ and $\mathrm{D}$ boxes. In this configuration, nitrate exhaustion in the $\mathrm{OMZ}$ is still not prevented, even though phytoplankton and nitrogen fixer concentrations are lower in the surface $\mathrm{U}$ and $\mathrm{S}$ boxes (Fig. 3m, n).

Two further sensitivity experiments were performed for each of the VID and OB configurations to explore how $\mathrm{NO}_{3}^{-}$ depletion in the UM box can be prevented. (1) Decreasing the fraction of export production remineralized in the UM box $\left(f_{\mathrm{UM}}\right)$ from 70 to $56 \%$ makes $\mathrm{NO}_{3}^{-}$persist in the UM box. Together with the $20 \%$ remineralization in the $\mathrm{U}$ box, this implies that $76 \%$ of the export production is remineralized in the upper $500 \mathrm{~m}$ of the ocean. However, the resulting $\mathrm{NO}_{3}^{-}$concentration in the UM box is far below the literature range of about 15 to $40 \mu \mathrm{mol} \mathrm{L}^{-1}$. (2) Facultative $\mathrm{N}_{2}$-fixation inhibits nitrogen fixation in an environment with high $\mathrm{NO}_{3}^{-}$ concentrations, but fails to prevent $\mathrm{NO}_{3}^{-}$depletion in the $\mathrm{UM}$ box.

The sensitivity with respect to the biogeochemical parameters (Sect. 2.5) is examined for all configurations. We only discuss the sensitivity of the OBRD configuration in Sect. 3.3, since the sensitivity experiments in all model configurations do not affect our main conclusion that fixed-N inventory can be stabilized at non-zero levels in the ETSP $\mathrm{OMZ}$ only if the remineralization rate via denitrification is slower than that via aerobic respiration. The model behaviour is very similar in all sensitivity experiments, with two exceptions. When $\mu_{\mathrm{NF}}$ is raised to $1 / 2 \mu$ and remineralization fractions in different boxes are rearranged to $f_{\mathrm{U}}=f_{\mathrm{S}}=60 \% \mathrm{com}$ bined with $f_{\mathrm{UM}}=f_{\mathrm{I}}=30 \%$, the VDRD and VIDRD configurations reach a steady state only in combination with facultative $\mathrm{N}_{2}$-fixation. 
Acknowledgements. The authors wish to acknowledge funding from the CSC (Chinese Scholarship Council), Sonderforschungsbereich 754 "Climate-Biogeochemistry Interaction in the Tropical Ocean" (www.sfb754.de) supported by the Deutsche Forschungsgemeinschaft, the EU FP7 project CARBOCHANGE "Changes in carbon uptake and emissions by oceans in a changing climate" (Grant agreement no. 264879) and the Cluster of Excellence "The Future Ocean", Kiel, Germany. The authors also wish to thank Ivonne Montes and Christopher Somes for the many helpful and inspiring discussions, and Christopher Somes and Tim DeVries for providing their model results of the ETSP. The very constructive comments that helped improve the manuscript from the two anonymous reviewers are highly appreciated.

Edited by: S. W. A. Naqvi

\section{References}

Anderson, L. A. and Sarmiento, J. L.: Redfield ratios of remineralization determined by nutrient data analysis, Global Biogeochem. Cy., 8, 65-80, doi:10.1029/93GB03318, 1994.

Bethoux, J. P.: Oxygen consumption, new production, vertical advection and environmental evolution in the Mediterranean Sea, Deep-Sea Res., 36, 769-781, doi:10.1016/0198-0149(89)901507, 1989.

Bianchi, D, Dunne,J. P., Sarmiento, J. L. and Galbraith,E. D.: Databased estimates of suboxia, denitrification, and $\mathrm{N}_{2} \mathrm{O}$ production in the ocean and their sensitivities to dissolved $\mathrm{O}_{2}$, Global Biogeochem. Cy., 26,1-13, doi:10.1029/2011GB004209, 2012.

Breitbarth, E, Oschlies, A. and LaRoche, J.: Physiological constrains on the global distribution of Trichodesmium-effect of temperature on diazotropy, Biogeosciences, 4, 53-61, doi:10.5194/bg-4-53-2007, 2007.

Bulow, S. E., Rich, J. J., Naik, H. S., Pratihary, A. K., and Ward, B. B.: Denitrification exceeds anammox as a nitrogen loss pathway in the Arabian Sea oxygen minimum zone, Deep-Sea Res. Pt. I, 57, 384-393, doi:10.1016/j.dsr.2009.10.014, 2010.

Canfield, D.: Models of oxic respiration, denitrification and sulfate reduction in zones of coastal upwelling, Geochim. Cosmochim. Ac., 70, 5753-5765, doi:10.1016/j.gca.2006.07.023, 2006.

Capone, D. G. and Knapp, A. N.: A marine nitrogen cycle fix?, Nature, 445, 159-160, doi:10.1038/445159a, 2007.

Capone, D. G., Zehr, J. P., Paerl, H. W., Bergman, B., and Carpenter, E. J.: Trichodesmium, a globally significant marine cyanobacterium, Science, 276, 1221-1229, doi:10.1126/science.276.5316.1221, 1997.

Caron, D. A. and Dennett, M. R.: Phytoplankton growth and mortality during the 1995 Northeast Monsoon and Spring Intermonsoon in the Arabian Sea, Deep-Sea Res. Pt. II, 46, 1665-1690, doi:10.1016/S0967-0645(99)00039-9, 1999.

Chu. S. P.: The utilization of organic phosphorus by phytoplankton, J. Mar. Biol. Assoc. U. K., 26, 285-295, 1946.

Cline, J. D. and Richards, F. A.: Oxygen deficient conditions and nitrate reduction in the Eastern Tropical North Pacific Ocean, Limnol. Oceanogr., 17, 885-900, 1972.

Codispoti, L. A.: Is the ocean losing nitrate?, Nature, 376, 724, doi:10.1038/376724a0, 1995.
Codispoti, L. A.: An oceanic fixed nitrogen sink exceeding $400 \mathrm{Tg} \mathrm{Na}^{-1}$ vs the concept of homeostasis in the fixed-nitrogen inventory, Biogeosciences, 4, 233-253, doi:10.5194/bg-4-2332007, 2007.

Codispoti, L. A. and Christensen, J.: Nitrification, denitrification and nitrous oxide cycling in the Eastern Tropical South Pacific Ocean, Mar. Chem., 16, 277-300, doi:10.1016/03044203(85)90051-9, 1985.

Codispoti, L. A. and Packard, T.: Denitrification rates in the eastern tropical South Pacific, J. Mar. Res., 38, 453-477, 1980.

Codispoti, L. A. and Richards, F.: An analysis of the horizontal regime of denitrification in the eastern tropical North Pacific, Limnol. Oceanogr., 21, 379-388, 1976.

Codispoti, L. A., Brandes, J., Christensen, J., Devol, A., Naqvi, S., Paerl, H., and Yoshinari, T.: The oceanic fixed nitrogen and nitrous oxide budgets: moving targets as we enter the anthropocene?, Sci. Mar., 65, doi:10.3989/scimar.2001.65s285, 2001.

Cotner, Jr.,J. B. and Wetzel., R. G.: Uptake of dissolved inorganic and organic bphosphorus compounds by phytoplankton and bacterioplankton, Limnol. Oceanogr., 37, 232-243, doi:10.4319/lo.1992.37.2.0232, 1992.

Dalsgaard, T., Thamdrup, B., and Canfield, D. E.: Anaerobic ammonium oxidation (anammox) in the marine environment, Res. Microbiol., 156, 457-464, doi:10.1016/j.resmic.2005.01.011, 2005.

Deutsch, C., Sigman, D. M., Thunell, R. C., Meckler, A. N., and Haug, G. H.: Isotopic constraints on glacial/interglacial changes in the oceanic nitrogen budget, Global Biogeochem. Cy., 18, GB4012, doi:10.1029/2003GB002189, 2004.

Deutsch, C., Sarmiento, J. L., Sigman, D. M., Gruber, N., and Dunne, J. P. Spatial coupling of nitrogen inputs and losses in the ocean, Nature, 445, 163-167, doi:10.1038/nature05392, 2007.

DeVries, T., Deutsch, C., Primeau, F., Chang, B., and Devol, A.: Global rates of water-column denitrification derived from nitrogen gas measurements, Nature, 5, 547-550, doi:10.1038/NGEO1515, 2012.

DeVries, T., Deutsch, C., Rafter, P., A., and Primeau, F.: Marine denitrification rates determined from a global 3-d inverse model, Biogeosciences, 10, 2481-2496, doi:10.5194/bg-10-2481-2013, 2013.

Devol, A. H. and Hartnett., H. E.: Role of the oxygen-deficient zone in transfer of organic carbon to the deep ocean, Limnol. Oceanogr., 46, 1684-1690, doi:10.4319/lo.2001.46.7.1684, 2001.

Eppley, R. W., Rogers, J. N., and McCarthy, J. J.: Halfsaturation constants for uptake of nitrate and ammonium by marine phytoplankton, Limnol. Oceanogr., 14, 912-920, doi:10.4319/lo.1969.14.6.0912, 1969.

Eugster, O. and Gruber, N.: A probabilistic estimate of global marine $\mathrm{N}$-fixation and denitrification, Global Biogeochem. Cy., 26, 1-15, doi:10.1029/2012GB004300, 2012.

Franz, J. M. S., Hauss, H., Sommer, U., Dittmar, T., and Riebesell, U.: Production, partitioning and stoichiometry of organic matter under variable nutrient supply during mesocosm experiments in the tropical Pacific and Atlantic Ocean, Biogeosciences, 9, 4629-4643, doi:10.5194/bg-9-4629-2012, 2012.

Fernandez, C., Farías, L., and Ulloa, O.: Nitrogen fixation in denitrified marine waters, PLoS ONE, 6, e20539, doi:10.1371/journal.pone.0020539, 2011. 
Furnas, M. J.: In situ growth rates of marine phytoplankton: approaches to measurement, community and species growth rates, J. Plankton Res., 12, 1117-1151, doi:10.1093/plankt/12.6.1117, 1990.

Galloway, J. N., Dentener, F. J., Capone, D. G., Boyer, E. W., Howarth, R. W., Seitzinger, S. P., Asner, G. P., Cleveland, C. C., Green, P. A., Holland, E. A., Karl, D. M., Michaels, A. F., Porter, J. H., Townsend, A. R., and Vörösmarty, C. J.: Nitrogen cycles: past, present and future, Biogeochemistry, 70, 153-226, doi:10.1007/s10533-004-0370-0, 2004.

Ganachaud, A. and Wunsch, C.: Oceanic nutrients and oxygen transports and bounds on export production during the World Ocean Circulation Experiment, Global Biogeochem. Cy., 16, 114, doi:10.1029/2000GB001333, 2002.

Garcia, H. E., Locarnini, R. A., Boyer, T. P., Antonov, J. I., Baranova, O. K., Zweng, M. M., and Johnson, D. R.: Volume 3: dissolved oxygen, apparent oxygen utilization, and oxygen saturation, in: World Ocean Atlas 2009, edited by: Levitus, S., NOAA Atlas NESDIS 70, US Government Printing Office, Washington, DC, p. 344, 2010a.

Garcia, H. E., Locarnini, R. A., Boyer, T. P., Antonov, J. I., Zweng, M. M., Baranova, O. K., and Johnson, D. R.: Volume 4: nutrients (phosphate, nitrate, silicate), in: World Ocean Atlas 2009, NOAA Atlas NESDIS 71, US Government Printing Office, Washington, D. C., p. 398, 2010b.

Gruber, N.: The dynamics of the marine nitrogen cycle and its influence on atmospheric $\mathrm{CO}_{2}$ variations, in: The Ocean Carbon Cycle and Climate, edited by: Follows, M. and Oguz, T., vol. 40 of NATO Science Series, Kluwer Academic, Dordrecht, the Netherlands, chap. 4, 97-148, 2004.

Gruber, N. and Sarmiento, J. L.: Global patterns of marine nitrogen fixation and denitrification, Global Biogeochem. Cy., 11, 235266, doi:10.1029/97GB00077, 1997.

Hamersley, M. R., Lavik, G., Woebken, D., Rattray, J. E., Lam, P., Hopmans, E. C., Damsté, J. S. S., Krüger, S., Graco, M., Gutiérrez, D., and Kuypers, M. M. M.: Anaerobic ammonium oxidation in the Peruvian oxygen minimum zone, Limnol. Oceanogr., 52, 923-933, doi:10.4319/lo.2007.52.3.0923, 2007.

Holl, C. M. and Montoya, J. P.: Interactions between nitrate uptake and nitrogen fixation in continuous cultures of the marine diazotroph Trichodesmium (cyanobacteria), J. Phycol., 41, 11781183, doi:10.1111/j.1529-8817.2005.00146.x, 2005.

Houlton, B. Z., Wang, Y.-P., Vitousek, P. M., and Field, C. B: A unifying framework for dinitrogen fixation in the terrestrial biosphere, Nature, 454, 327-331, doi:10.1038/nature07028, 2008.

Kalvelage, T., Lavik, G., Lam, P., Contreras, S., Arteaga, L., Löscher, C. R., Oschlies, A., Paulmier, A., Stramma, L., and Kuypers, M. M. M.: Nitrogen cycling driven by organic matter export in the South Pacific oxygen minimum zone, Nat. Geosci., 6, 228-234, doi:10.1038/NGEO1739, 2013.

Key, R. M., Kozyr, A., Sabine, C. L., Lee, K., Wanninkhof, R., Bullister, J. L., Feely, R. A., Millero, F. J., Mordy, C., and Peng, T.-H.: A global ocean carbon climatology: results from Global Data Analysis Project (GLODAP), Global Biogeochem. Cy., 18, 1-23, doi:10.1029/2004GB002247, 2004.

Kuypers, M. M. M., Lavik, G., Woebken, D., Schmid, M., Fuchs, B. M., Amann, R., Jørgensen, B. B., and Jetten, M. S. M.: Massive nitrogen loss from the Benguela upwelling system through anaerobic ammonium oxidation, P. Natl. Acad. Sci USA, 102, 6478-6483, doi:10.1073/pnas.0502088102, 2005.

La Roche, J. and Breitbarth, E.: Importance of the diazotrophs as a source of new nitrogen in the ocean, J. Sea Res., 53, 67-91, doi:10.1016/j.seares.2004.05.005, 2005.

Landolfi, A., Dietze, H., Koeve, W., and Oschlies, A.: Overlooked runaway feedback in the marine nitrogen cycle: the vicious cycle, Biogeosciences, 10, 1351-1363, doi:10.5194/bg-10-1351-2013, 2013.

Lenton, T. M. and Watson, A. J.: Redfield revisited 1. Regulation of nitrate, phosphate, and oxygen in the ocean, Global Biogeochem. Cy., 14, 225-248, doi:10.1029/1999GB900065, 2000.

Libby, W. F.: Radiocarbon dating, Am. Sci., 44, 98-112, 1956.

Liu, K.-K. and Kaplan, I. R.: Denitrification rates and availability of organic matter in marine environments, Earth Planet. Sc. Lett., 68, 88-100, doi:10.1016/0012-821X(84)90142-0, 1984.

Martin, J. H., Knauer, G. A., Karl, D. M., and Broenkow, W. W.: VERTEX: carbon cycling in the northeast Pacific, Deep-Sea Res., 34, 267-285, 1987.

McAllister, C. D., Shah, N., and Strickland, J. D. H.: Marine phytoplankton photosynthesis as a function of light intensity: a comparison of methods, J. Fish. Res. Board Can., 21, 159-181, doi:10.1139/f64-010, 1964.

Mills, M. M. and Arrigo, K. R.: Magnitude of oceanic nitrogen fixation influenced by the nutrient uptake ratio of phytoplankton, Nat. Geosci., 3, 412-416, doi:10.1038/NGEO856, 2010.

Mills, M. M., Ridame, C., Davey, M., La Roche, J., and Geider, R. J.: Iron and phosphorus co-limit nitrogen fixation in the eastern tropical North Atlantic, Nature, 429, 292-232, doi:10.1038/nature02550, 2004.

Molina, V. and Farías, L.: Aerobic ammonium oxidation in the oxycline and oxygen minimum zone of the eastern tropical South Pacific off northern Chile $\left(\sim 20^{\circ} \mathrm{S}\right)$, Deep-Sea Res. Pt. II, 56, 1032-1041, doi:10.1016/j.dsr2.2008.09.006, 2009.

Monteiro, F. M., Follows, M. J., and Dutkiewicz, S.: Distribution of diverse nitrogen fixers in the global ocean, Global Biogeochem. Cy., 24, 1-16, doi:10.1029/2009GB003731, 2010.

Moore, J. K. and Doney, S. C.: Iron availability limits the ocean nitrogen inventory stabilizing feedbacks between marine denitrification and nitrogen fixation, Global Biogeochem. Cy., 21, 1-12, doi:10.1029/2006GB002762, 2007.

Morrison, J., Codispoti, L., Gaurin, S., Jones, B., Manghnani, V., and Zheng, Z.: Seasonal variation of hydrographic and nutrient fields during the US JGOFS Arabian Sea Process Study, Deep-Sea Res. Pt. II, 45, 2053-2101, doi:10.1016/S09670645(98)00063-0, 1998.

Palmer, J. and Totterdell, I.: Production and export in a global ocean ecosystem model, Deep-Sea Res. Pt. I, 48, 1169-1198, doi:10.1016/S0967-0637(00)00080-7, 2001.

Paulmier, A. and Ruiz-Pino, D.: Oxygen minimum zones (OMZs) in the modern ocean, Prog. Oceanogr., 80, 113-128, doi:10.1016/j.pocean.2008.08.001, 2009.

Redfield, A. C., Ketchum, B. H., and Richards, F. A.: The influence of organisms on the composition of sea-water, in: The Sea, 2677, 1963.

Robarts, R. D. and Zohary, T.: Temperature effects on photosynthetic capacity, respiration, and growth rates of bloom forming cyanobacteria, New Zeal. J. Mar. Fresh., 21, 391-399, doi:10.1080/00288330.1987.9516235, 1987. 
Schmittner, A., Oschlies, A., Matthews, H. D., and Galbraith, E. D.: Future changes in climate, ocean circulation, ecosystems, and biogeochemical cycling simulated for a business-as-usual $\mathrm{CO}_{2}$ emission scenario until year $4000 \mathrm{AD}$, Global Biogeochem. Cy., 22, GB1013, doi:10.1029/2007GB002953, 2008.

Shaffer, G. and Sarmiento, J. L.: Biogeochemical cycling in the global ocean 1. A new, analytical model with continuous vertical resolution and high-latitude dynamics, J. Geophys. Res., 100, 2659-2672, doi:10.1029/94JC01167, 1995.

Somes, C. J., Schmittner, A., Galbraith, E. D, Lehmann, M. F., Altabet, M. A., Montoya, J. P., Letelier, R. M., Mix, A. C., Bourbonnais, A., and Eby, M.: Simulating the global distribution of nitrogen isotopes in the ocean, Global Biogeochem. Cy., 24, 116, doi:10.1029/2009GB003767, 2010.

Suess, E.: Particulate organic carbon flux in the ocean surface productivity and oxygen utilization, Nature, 288, 260-263, doi:10.1038/288260a0, 1980.

Toggweiler, J. R., Dixon, K., and Bryan, K.: Simulations of radiocarbon in a coarse-resolution world ocean model 1. Steady state prebomb distributions, J. Geophys. Res., 94, 8217-8242, doi:10.1029/JC094iC06p08217, 1989.
Tyrrell, T.: The relative influences of nitrogen and phosphorus on oceanic primary production, Nature, 400, 525-531, 1999.

Van Mooy, B. A. S., Keil, R. G., and Devol, A. H.: Impact of suboxia on sinking particulate organic carbon: enhanced carbon flux and preferential degradation of amino acids via denitrification, Geochim. Cosmochim. Ac., 66, 457-467, doi:10.1016/S00167037(01)00787-6, 2002.

Voss, M., Dippner, J. W., and Montoya, J. P.: Nitrogen isotope patterns in the oxygen-deficient waters of the Eastern Tropical North Pacidic Ocean, Deep-Sea Res. Pt. I, 48, 1905-1921, doi:10.1016/S0967-0637(00)00110-2, 2001.

Ward, B. B., Devol, A. H., Rich, J. J., Chang, B. X., Bulow, S. E., Naik, H., Pratihary, A., and Jayakumar, A.: Denitrification as the dominant nitrogen loss process in the Arabian Sea, Nature, 461, 78-81, doi:10.1038/nature08276, 2009.

Ye, Y., Völker, C., Bracher, A.,Taylor, B., and WolfGladrow., D. A.: Environmental controls on $\mathrm{N}_{2}$ fixation by Trichodesmium in the tropical eastern North Atlantic Ocean - A model-based study, Deep-Sea Res. I, 64, 104-117, doi:10.1016/j.dsr.2012.01.004, 2012. 